\title{
REVIEW
}

\section{Onto better TRAILs for cancer treatment}

\author{
D de Miguel ${ }^{\star, 1,2}$, J Lemke $^{3,5}$, A Anel $^{1,2}$, H Walczak $^{3}$ and L Martinez-Lostao*,1,2,4,6
}

Tumor necrosis factor (TNF)-related apoptosis-inducing ligand (TRAIL), also known as Apo-2 ligand (Apo2L), is a member of the TNF cytokine superfamily. By cross-linking TRAIL-Receptor (TRAIL-R) 1 or TRAIL-R2, also known as death receptors 4 and 5 (DR4 and DR5), TRAIL has the capability to induce apoptosis in a wide variety of tumor cells while sparing vital normal cells. The discovery of this unique property among TNF superfamily members laid the foundation for testing the clinical potential of TRAIL-Rtargeting therapies in the cancer clinic. To date, two of these therapeutic strategies have been tested clinically: (i) recombinant human TRAIL and (ii) antibodies directed against TRAIL-R1 or TRAIL-R2. Unfortunately, however, these TRAIL-R agonists have basically failed as most human tumors are resistant to apoptosis induction by them. It recently emerged that this is largely due to the poor agonistic activity of these agents. Consequently, novel TRAIL-R-targeting agents with increased bioactivity are currently being developed with the aim of rendering TRAIL-based therapies more active. This review summarizes these second-generation novel formulations of TRAIL and other TRAIL-R agonists, which exhibit enhanced cytotoxic capacity toward cancer cells, thereby providing the potential of being more effective when applied clinically than first-generation TRAIL-R agonists.

Cell Death and Differentiation (2016) 23, 733-747; doi:10.1038/cdd.2015.174; published online 4 March 2016

Facts

- On its discovery, TRAIL was described to be capable of inducing apoptosis selectively in cancer cells. However, soon afterwards it was found that many cancer cell lines as well as primary cancer cells are either intrinsically TRAILresistant, or become resistant upon TRAIL treatment.

- The results from TRAIL using clinical trials have been disappointing, showing little antitumor efficacy. All these clinical trials have used a soluble form of the protein, which is known to be rather unstable and to have poor physicochemical properties.

- TRAIL has four receptors that are expressed at the plasma membrane, of which two can trigger apoptosis. Little is known about the relative contribution or differential roles of these two pro-apoptotic TRAIL receptors (TRAIL-Rs).

- Physiologically, TRAIL is expressed as a transmembrane protein. This fact may be exploitable therapeutically since membrane-bound as well as artificially cross-linked TRAIL is by several orders of magnitude more active than conventional soluble trimeric TRAIL.

- New TRAIL formulations with increased bioactivity due to improved stability and/or cross-linking efficiency have been developed. Besides, new approaches trying to combine inherent TRAIL pro-apoptotic ability with delivery systems based on nanoparticles are also being explored.

\section{Open Questions}

- Could new forms of TRAIL or other TRAIL-R agonist formulations with increased bioactivity, improved pharmacokinetic and targeting properties contribute to overcoming TRAIL resistance without causing systemic toxicity?

- Could such novel TRAIL-R-targeting biotherapeutics exert improved synergy with known TRAIL-sensitizing agents, over TRAIL-R agonists used clinically to date?

Despite remarkable advances in understanding the biology of cancer and the development of novel diagnostic and therapeutic strategies, cancer still remains one of the major causes of death. To date, in addition to surgical resection of the tumor, conventional radio- and chemotherapy constitute the central pillars of cancer treatment. These therapies aim to limit proliferation and/or induce the death of cancer cells. However, they mostly lack cancer specificity and, therefore, also damage normal, healthy tissues resulting in often severe side effects that constitute the dose-limiting toxicities. In addition, many cancers acquire resistance to these therapies, rendering them ineffective in consecutive treatment rounds. Hence, during the past decades great efforts have been made to develop new therapeutic approaches, aiming to improve the specific targeting of cancer cells and to overcome resistance to current therapies. ${ }^{1,2}$

\footnotetext{
${ }^{1}$ Departamento de Bioquímica, Biología Molecular y Celular, Facultad de Ciencias, Universidad de Zaragoza, Zaragoza, Spain; ${ }^{2}$ Instituto de Investigación Sanitaria de Aragón, Zaragoza, Spain; ${ }^{3}$ UCL Cancer Institute, Faculty of Medical Sciences, University College London, London, UK and ${ }^{4}$ Instituto de Nanociencia de Aragón, Zaragoza, Spain

${ }^{*}$ Corresponding author: D de Miguel or L Martinez-Lostao, Departamento de Bioquímica, Biología Molecular y Celular, Facultad de Ciencias, Universidad de Zaragoza, C/Pedro Cerbuna 12, 50009 Zaragoza, Spain. Tel: +34 97676 12 87; Fax: +34 9767621 23; E-mail: diego_demiguel@ hotmail.com or lumartin@unizar.es

${ }^{5}$ Current address: Clinic of General and Visceral Surgery, Universität Ulm, Ulm, Germany

${ }^{6}$ Current address: Servicio de Inmunología, Hospital Clínico Universitario Lozano Blesa, Avda/San Juan Bosco 15, Zaragoza 50009, Spain

Received 21.8.15; revised 11.12.15; accepted 17.12.15; Edited by G Melino; published online 04.3.16
} 
The better understanding of tumor biology, tumor immunology and how cancer cells interact with the tumor microenvironment, sparked the development of cancer immune-therapeutics as well as so-called targeted cancer therapeutics. $^{2-5}$ The identification of the tumor necrosis factor (TNF)-related apoptosis-inducing ligand (TRAIL), also referred to as Apo-2 ligand (Apo2L), ${ }^{6,7}$ and most importantly, the discovery of TRAIL's capacity to kill cancer cells while sparing all the vital normal cells, ${ }^{8}$ appeared to represent a promising step forward in the development of targeted anticancer therapies. TRAIL belongs to the TNF superfamily (SF) of cytokines and is capable of inducing apoptosis in cells by binding to either of two cognate death receptors (DRs), TRAIL-R1/DR4 (ref. 9) and TRAIL-R2/DR5. ${ }^{10-14}$ Physiologically, TRAIL has been implicated in the function of cytotoxic effector cells ${ }^{15,16}$ and the homeostasis of the lymphoid compartment by being a mediator of activation-induced cell death (AICD) in effector immune cells. ${ }^{17}$

Given the cancer-selective apoptosis-inducing potential of TRAIL and the fact that TRAIL-R1 and, even more so, TRAIL-R2 are often highly expressed in different malignancies, ${ }^{9,13,14,18-23}$ the use of TRAIL or other agonists for TRAIL-R1/R2 for cancer therapy appeared an attractive concept. Consequently, TRAIL-R agonists were developed for clinical application. The results of the clinical studies performed with these first-generation TRAIL-R agonists so far have been rather disappointing, however, with limited patient benefit despite promising pre-clinical results. ${ }^{24-26}$ The fact that many human tumors are partially or completely resistant to monotherapy with TRAIL and other TRAIL-R agonists likely contributed to the limited therapeutic activity observed in these studies. However, another-perhaps decisive-factor for the lack of clinical efficacy of the specific TRAIL-R agonists that have been tested clinically most likely is that their agonistic capacity was simply not sufficiently potent. This is exemplified by a recent study in which it was shown that, only when used in combination, two of the abovementioned clinically developed TRAIL-R agonists exerted virtually the same agonistic activity as isoleucine zipperTRAIL (iz-TRAIL), ${ }^{27}$ a highly active form of TRAIL that has been in use for some time $e^{28-30}$ and is based on the original leucine-zipper form of TRAIL (LZ-TRAIL) used in the study in which TRAIL's tumor-selective apoptosis-inducing potential was discovered, importantly, in the absence of systemic toxicity. ${ }^{8}$ Unfortunately, this fact went largely unnoticed and because of safety concerns with certain more potent forms of TRAIL, ${ }^{31}$ several TRAIL-R agonists with, as it turned out, insufficient agonistic activity and consequently pro-apoptotic potency were developed for clinical use. Yet, the fact that to date no sufficiently potent TRAIL-R agonist that lacks systemic toxicity has been clinically validated, has led to the development of novel formulations of TRAIL and other TRAIL-R agonists with improved bioactivity, with the aim to overcome TRAIL resistance in combination with improved sensitization strategies and patient-selection criteria. ${ }^{32}$

This review summarizes the main novel formulations of such TRAIL-R agonists that are currently being tested or developed to improve biological attributes such as stability, delivery, targeting and cytotoxic activity against tumor cells as well as their potential for applications in cancer therapy.

\section{TRAIL signaling}

Physiologically, TRAIL is expressed as a type 2 transmembrane protein that can be cleaved, resulting in the release of a $24 \mathrm{kDa}$ extracellular portion comprising amino acids 114-281 of the protein. The C-terminal extracellular domain of TRAIL shares high homology with other members of the TNF SF and is composed of two anti-parallel $\beta$-sheets. ${ }^{33-35}$ As shown by the crystal structure of TRAIL interacting with TRAIL-R2, TRAIL forms a trimer and each receptor molecule interacts with the crevice formed by two monomers of the trimer. Thereby, the TRAIL trimer can engage three receptors simultaneously. Interestingly, unlike other TNF SF members, the ligand trimer appears to be stabilized by an internal zinc atom, which interacts non-covalently with three cysteine residues, one from each TRAIL monomer. This interaction is thought to be crucial for the stability, solubility and bioactivity of trimeric TRAIL. ${ }^{33-35}$

TRAIL can bind to four transmembrane receptors: TRAILR1, TRAIL-R2, TRAIL-R3, also known as decoy receptor 1 (DcR1) and TRAIL-R4 (DcR2), as well as to the soluble receptor osteoprotegerin (OPG). ${ }^{9,13,36-39}$ Among them, only TRAIL-R1 and TRAIL-R2 are able to trigger apoptosis as TRAIL-R3, TRAIL-R4 and OPG lack the functional cytoplasmic death domain (DD) that is required for apoptosis induction. ${ }^{40,41}$ On the basis of overexpression experiments, TRAIL-R3 and TRAIL-R4 have been suggested to act as decoy receptors that inhibit apoptosis induction by TRAIL as a consequence of ligand scavenging. ${ }^{23,42}$ In addition, TRAIL-R4 has been proposed to be capable of inhibiting TRAIL-induced apoptosis by forming ligand-independent inactive complexes with TRAIL-R2 or the induction of pro-survival pathways such as NF- $\kappa B^{43-45}$ However, there is still controversy concerning the physiological role of TRAIL-R3 and TRAIL-R4, and their function might depend on the cell type. For example, and in contrast to the mentioned studies, these receptors have also been described not to function as DcRs in the human hepatocellular carcinoma cell lines Hep3b and a TRAILresistant variant of HepG2 (HepG2-TR). ${ }^{46}$

TRAIL triggers the extrinsic apoptosis pathway upon binding of the TRAIL trimer to TRAIL-R1 and/or TRAIL-R2, resulting in receptor trimerization, which in turn leads to recruitment of the adaptor protein Fas-associated DD (FADD) via homotypic DD-DD interaction between the DDs of the ligand cross-linked receptors and FADD, respectively. FADD, in turn, recruits pro-caspase- 8 and pro-caspase-10 via homotypic interactions of death-effector domains (DED) present both in FADD and caspase-8 and -10, respectively. This multi-protein complex formed by TRAIL-DRs, FADD and caspase-8/10 is called death-inducing signaling complex (DISC). ${ }^{47-51}$ On recruitment to the DISC, the pro-caspases-8 and -10 form homodimers. This induces a conformational change that exposes their proteolytically active sites, resulting in auto-activation and subsequent cleavage of additional procaspase-8 and -10 molecules leading to full caspase activation at the DISC. ${ }^{52-55}$

TRAIL can activate both branches of the apoptosis pathway by caspase-8-mediated cleavage and activation of the effector caspase-3 and the BH3-only protein Bid. In so-called type I cells, cleavage and activation of caspase- 3 by activated 
caspase-8 is sufficient to induce apoptosis, whereas in type II cells, activation of the mitochondrial pathway is required for apoptosis induction as a consequence of TRAIL DISC activation. ${ }^{56,57}$ The latter is triggered by caspase-8-mediated cleavage of Bid, which results in the formation of truncated Bid (tBid) as the active fragment of this protein. ${ }^{58-61}$ Subsequently, tBid activates the mitochondrial pathway by enabling the pro-apoptotic Bcl2-family members Bax and Bak to insert in the mitochondrial outer membrane (MOM), resulting in MOM permeabilization (MOMP) and release of cytochrome $C$ and Smac/DIABLO (second mitochondrial activator of caspases/ direct inhibitor of apoptosis-binding protein with low pl) ${ }^{62,63}$ from the mitochondrial intermembrane space into the cytosol. $^{64,65}$

Although TRAIL-R1 and TRAIL-R2 bear high structural similarity and both are able to trigger apoptosis upon TRAIL-induced cross-linking, functional differences between them have been reported. First, TRAIL-R2 has higher affinity for TRAIL than TRAIL-R1. ${ }^{66}$ Yet, higher affinity does not necessarily result in enhanced DISC activation as although TRAIL-R2 can be engaged by the soluble ligand, this interaction only triggers a comparably weak DISC formation. ${ }^{67}$ This result supports the notion that TRAIL-R2 may require further cross-linking of soluble TRAIL (sTRAIL), whereas stimulation of TRAIL-R1 by STRAIL appears to be able to trigger apoptosis independently of further crosslinking. ${ }^{68,69}$ However, recently it was shown that oligomerized TRAIL versions can also activate TRAIL-R1 more efficiently than sTRAIL. ${ }^{70}$ Altogether, it seems clear that TRAIL presents a much stronger activity when it is presented in its transmembrane form than their soluble counterparts, and this enhanced activity is directly linked to its ability to cluster and arrange their specific receptors in supramolecular structures. In line with this, several studies showed that clustering of two trimers was sufficient to improve their activity to optimal levels for the other members of the TNF family ligands. ${ }^{71,72}$ The requirement for oligomerization for optimal agonistic activity has also been proposed for the other members of the TNF SF, including CD95L (also known as FasL or APO-1L) whose ability to induce apoptosis is dramatically increased (up to 1.000 -fold) on clustering of soluble trimers. ${ }^{73,74}$ Once clustered, the receptors adopt a supramolecular hexagonal organization, similar to a 'honeycomb' structure. ${ }^{75}$ In line with this, several studies showed that dimerization of two trimers was sufficient to improve their activity to optimal or nearoptimal levels. ${ }^{71,72}$ The clustering of DRs achieved thereby most likely facilitates and stabilizes DISC assembly. ${ }^{75-77}$

Along these lines, a new way to improve sTRAIL bioactivity by enhancing TRAIL-R2 clustering was described very recently. ${ }^{27,78}$ In these studies, STRAIL was used in combination with the TRAIL-R2-specific agonistic antibody AMG-655/ Conatumumab. Of note, both sTRAIL and AMG-655 had been developed to be used individually as novel anticancer biotherapeutics and had already been tested in clinical trials as discussed in more detail below. Co-administration of AMG-655 and STRAIL was able to greatly enhance the inherent ability of STRAIL to activate TRAIL-R2, even sensitizing certain cancer cell lines that are resistant to sTRAIL. This synergistic effect was due to secondary TRAIL-R2 crosslinking exerted by the antibody, which acted in cooperation with the normal engagement of TRAIL-R2 exerted by STRAIL. In a similar way, a recent work has used another specific TRAIL-R2 antibody in combination with STRAIL, obtaining the same synergistic effect. ${ }^{67}$

It is, however, still largely unresolved what the relative contribution of the two individual TRAIL-DRs to apoptosis induction in a given cancer is. Although TRAIL-R1 has been described to mediate cell death in chronic lymphocytic leukemia cells, acute myelogenous leukemia cells and pancreatic tumors, ${ }^{79-82}$ TRAIL-R2 appears to be the main contributor to apoptosis induction in several other epithelialderived cancers. ${ }^{83,84}$ This differential pro-apoptotic performance of TRAIL-R1 and TRAIL-R2 depending on the cell/ cancer type may be exploitable therapeutically by specifically targeting the receptor that is preponderant at inducing apoptosis in the particular cancer type in question. Such targeting may increase the specific cytotoxic effect by sparing non-apoptotic interactions with other TRAIL-Rs. Apart from antibody-based biotherapeutics, such receptor-specific TRAIL constructs can be generated by inducing point mutations in residues within the TRAIL sequence that are required for interaction with particular TRAIL-Rs and not others. A number of such TRAIL variants have been devised and have become valuable tools for assessing specific roles of the different TRAIL-Rs, and, moreover, have recently been shown to bear the potential of improving the efficacy of specifically activating TRAIL-R1 and TRAIL-R2, respectively. ${ }^{45,80,83,85-87}$

TRAIL-induced apoptosis is tightly regulated at different stages to prevent excessive cell death in normal cells. These mechanisms are exploited by tumor cells to evade TRAILinduced apoptosis. At the level of expression of the TRAIL-Rs it has been suggested that, as mentioned above, the nonapoptotic receptors TRAIL-R3, -R4 and/or OPG may modulate sensitivity to TRAIL. At the DISC level, the main regulator protein is cellular FLICE-Like Inhibitory Protein (cFLIP), that closely resembles caspase- 8 but lacks the protease activity required for apoptosis induction. ${ }^{88,89}$ Two main variants of cFLIP are expressed on the protein level: a short isoform (cFLIP $)$ and a long isoform (cFLIP $).{ }^{90}$ Both cFLIP isoforms contain two DEDs that are structurally similar to the DEDs present in the $\mathrm{N}$-terminal portion of pro-caspase-8 and -10 and allow recruitment to the DISC. The cFLIPS isoform can inhibit caspase- 8 activation in a dominant-negative manner by competing with it for binding to FADD. The role of $C F L I P_{L}$ is, however, more complex and seemingly depends on the ratio between caspase-8 and $\mathrm{CFLIP}_{\mathrm{L}} \cdot{ }^{91-93}$ Although $\mathrm{CFLIP}$, was first reported to act as an anti-apoptotic protein in a manner similar to $\mathrm{CFLIP}_{\mathrm{S}}{ }^{88}$ later studies demonstrated that the cFLIP $/$ /caspase-8 heterodimer, apart from retaining enzymatic activity, also displays an enhanced and more localized activity toward certain substrates when compared with the caspase-8 homodimer, somehow modulating caspase-8 substrate specificity. ${ }^{94-96}$ In fact, the activity of the $\mathrm{FLIP}_{\mathrm{L}} /$ caspase- 8 heterodimer is required to prevent necroptosis. ${ }^{91-93,97,98}$ Nevertheless, it should be noted that, when expressed at high levels, CFLIP $\mathrm{P}_{\mathrm{L}}$ can also completely prevent DR-induced apoptosis. Several studies have demonstrated that cancer cells exploit overexpression of cFLIP to evade TRAIL-induced apoptosis ${ }^{99-101}$ and, consequently, 
downregulation of cFLIP may sensitize certain cancers to TRAIL-induced apoptosis. ${ }^{46,102-105}$

Another important checkpoint in the apoptotic cascade is exerted by XIAP (X-linked inhibitor of apoptosis protein), a molecule that can bind caspases 3, 7 and 9, thereby inhibiting their pro-apoptotic activity. ${ }^{106}$ Several additional mechanisms of different nature can modulate TRAIL signaling. Posttranslational modifications such as O-glycosylation, which promotes ligand-stimulated clustering of TRAIL-DRs and recruitment/activation of procaspase- $8,{ }^{107}$ ubiquitination regulating the full activation of caspase-8 upon TRAIL stimulation $^{108}$ and endocytosis of the DISC upon TRAIL binding $^{109}$ are just a few examples of several mechanisms proposed to be implicated in the modulation of TRAIL signaling.

Apart from inducing apoptosis, TRAIL can also trigger nonapoptotic signaling such as necroptosis and the activation of pro-inflammatory pathways (via NF- $k \mathrm{~B}$, Akt, MAPK and JNK activation). Induction of these non-apoptotic pathways depends on the cell type and is often triggered in scenarios when apoptosis induction is inhibited. ${ }^{40,110-112}$ The induction of pathways resulting in gene activation has been suggested to be mediated by the formation of a secondary complex following DISC activation. This secondary complex also contains the DISC components FADD, caspase- 8 and CFLIP ${ }^{113}$ and, additionally, recruits receptor interacting protein 1 (RIP1), TNF receptor-associated factor 2 (TRAF2) and the $N F-\kappa B$ essential modulator (NEMO). ${ }^{114}$ Initially, TRAILinduced activation of pro-inflammatory pathways was proposed to be mainly a mechanism to negatively regulate apoptosis induction by TRAIL. However, activation of these pathways, such as NF- $k \mathrm{~B}, \mathrm{AKT}$ and MAP kinases can also enhance the malignancy of cancer cells by increasing their proliferation, migration, invasion and/or metastasis. ${ }^{115-117}$

In addition, both exogenous TRAIL and FasL were shown to induce proliferation and to promote migration in KRASmutated cancer cells upon external administration. ${ }^{118}$ These findings led to the recent discovery of a pro-invasive role for endogenous TRAIL in KRAS-mutated cells. In these cells, autocrine endogenous TRAIL stimulates cancer cellexpressed TRAIL-R2 to activate Rac1 which, in turn, activates PI3K to induce cell migration. ${ }^{119}$ Interestingly, activation of this signaling pathway was independent of TRAIL-R2's DD but instead required its membrane proximal domain (MPD). ${ }^{119}$

\section{TRAIL-R agonists as anticancer therapeutics}

So far, two main TRAIL-DR-targeting therapeutic strategies have being pursued in clinical trials: (i) a recombinant form of human STRAIL (Apo2L.0 or AMG-951/Dulanermin) and (ii) agonistic antibodies that specifically target TRAIL-R1 or TRAIL-R2. ${ }^{32}$ Although these TRAIL-R agonists have been shown to be safe and well tolerated in patients, their respective anticancer activities have been largely disappointing ${ }^{24-26}$ (extensively reviewed by Lemke et al. ${ }^{32}$ and Holland ${ }^{120}$ ). The fact that most primary tumor cells are intrinsically resistant to TRAIL or may acquire resistance during the course of treatment ${ }^{121-125}$ has most likely contributed to this failure.

In addition to these considerations, non-apoptotic signaling induced by TRAIL has been shown to be exploited by tumor cells, at least in certain cases, to their own advantage. For example, it has been shown that TRAIL promotes the development of liver metastasis in a pancreatic adenocarcinoma xenograft model, pointing toward potentially harmful effects of monotherapy with TRAIL-R agonists. ${ }^{116}$ In this context, it is noteworthy to mention that TRAIL-R1 expression positively correlates with tumor grade in patients with breast cancer. $^{126,127}$

To avoid the undesired pro-tumorigenic effects of monotherapy with TRAIL-R agonists in TRAIL-resistant cancers, it has been proposed to combine them with sensitizing agents (reviewed in Lemke et $a l,{ }^{32}$ ). However, regardless of the promising results obtained with such combinatorial approaches, careful evaluation, both pre-clinically and in early clinical testing, is needed as it may bear the risk of sensitizing a vital normal cell type to TRAIL-induced cell death. ${ }^{28-30,46}$

It is now clear that, besides adding more potent sensitizing agents to a TRAIL-R-agonist-comprising therapy, improvement of the agonistic capacities of TRAIL-R agonists is imperative to render TRAIL-based therapies effective. To enhance the therapeutic potential of TRAIL, different shortcomings of currently used TRAIL-R agonists need to be addressed. In the specific case of Apo2L.0/AMG-951/Dulanermin, the disappointing results obtained in clinical trials are most likely due to the combination of its short plasma half-life and rapid clearance from circulation ${ }^{128,129}$ with its limited ability to cluster TRAIL-DRs. It should be noted that antibodies directed to TRAIL-DRs have a comparably long half-life in serum, whereas their in vivo activity is hampered by the fact that they require external cross-linking to induce effective TRAIL-DR clustering and, hence, TRAIL-DRmediated apoptosis. ${ }^{130,131}$ To overcome these shortcomings and pharmacological downsides, novel TRAIL formulations have been developed with the aim to increase the efficiency of TRAIL-DR-targeting therapies (Figure 1).

These novel formulations improve the activity of TRAIL-R agonists by tackling the following two main aspects: (i) increasing stability and valency and (ii) enhancing cancerspecific delivery. A wide variety of experimental approaches are currently engineered to address these aspects, resulting in novel versions of TRAIL-R agonists with promising attributes, which will hopefully prove useful to cancer treatment in the future.

\section{Increasing the stability of TRAIL}

The correct conformation and stability of TRAIL has a crucial role for its biological activity since trimerization of TRAIL monomers is pivotal to induce TRAIL-R clustering on the cell surface. The physical and chemical changes can, however, result in the collapse of TRAIL's trimeric structure. ${ }^{31,33,34,132}$ Furthermore, TRAIL monomers can easily form disulfidelinked dimers that impairs its apoptotic potential by up to 90 fold. $^{34}$

The first recombinant versions of TRAIL comprised the extracellular portion of the protein or its TNF homology domain (THD) with an N-terminally added poly-Histidine tag (His-TRAIL ${ }^{6}$ ) or FLAG epitope tag (FLAG-TRAIL ${ }^{7}$ ). These tags were added merely to facilitate the purification process. Noteworthy, FLAG-TRAIL alone was poorly active, and 


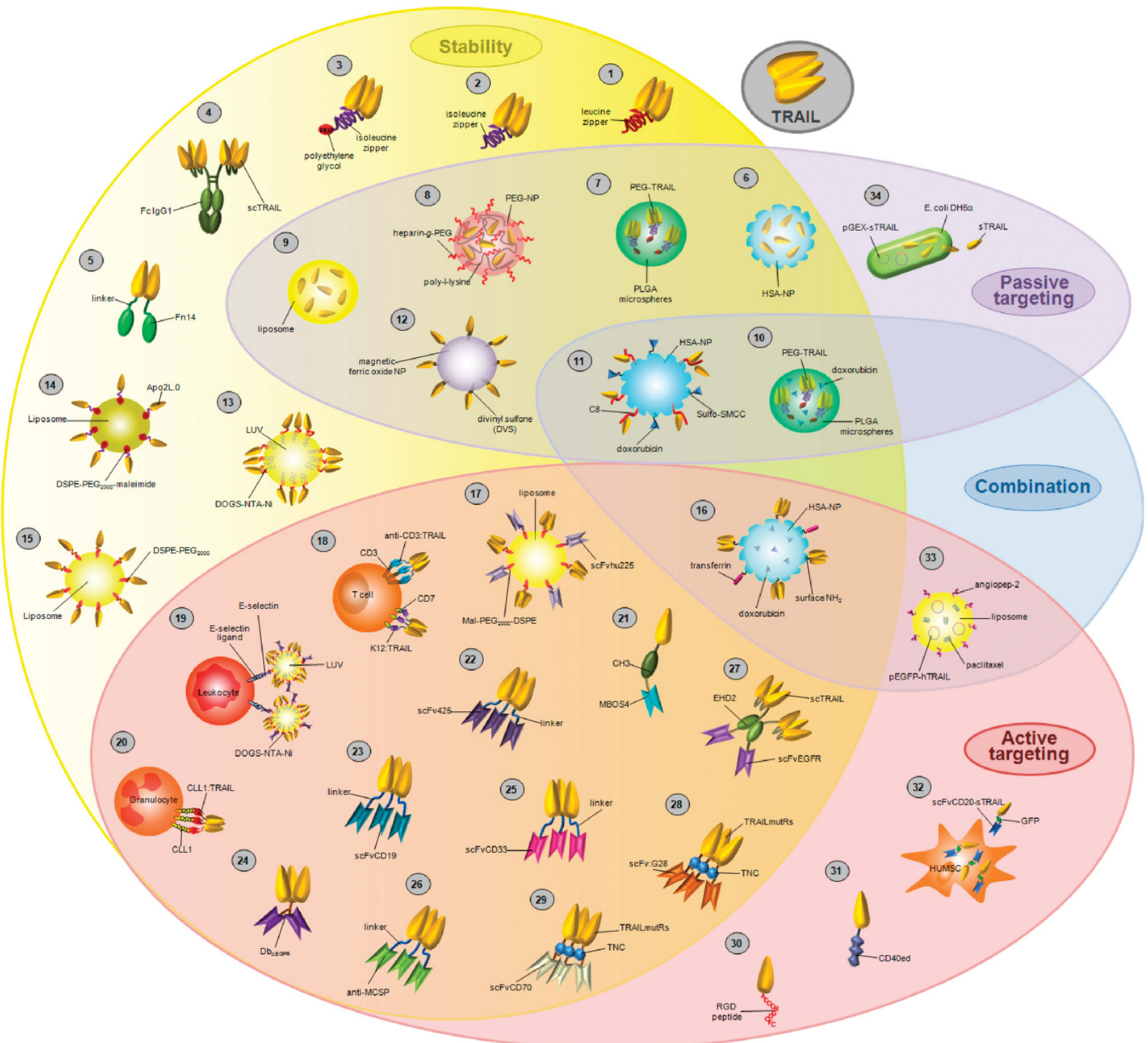

Figure 1 TRAIL formulations with increased bioactivity for cancer treatment. Different formulations of TRAIL using distinct experimental approaches have been developed to increase its therapeutic potential. These formulations are mainly based in fusion proteins with single-chain variable antibody fragments (scFv), conjugation with nanoparticles and, cell-based methods to express and/or secrete Apo2L/TRAIL. The main properties improved with these highly bioactive formulations are the increase of the molecule stability, tumor targeting and the possibility of combination with other antitumor agents in a unique formulation. References: 1: leucine zipper-TRAIL; 8,142 2: Isoleucine zipper-TRAIL homotrimer; ${ }^{30}$ 3: PEG-HZ-TRAIL; ;50,152 4: APG350; ${ }^{209}$ 5: Fn14:TRAIL; ${ }^{192,193}$ 6: TRAIL HSA-NPs; ${ }^{153}$ 7: PEG-TRAlL microspheres; ${ }^{152,169}$ 8: TRAIL-PEG-NPs; $1{ }^{154}$ 9: TRAILLPs; ${ }^{173,174,176}$ 10: PEG-TRAIL/Dox microspheres; ${ }^{151}$ 11: TRAIL/Dox HSA-NPs; ${ }^{167}$ 12: magnetic NPs-TRAlL; ${ }^{170}$ 13: LUV-TRAIL; $67,171,172,212$ 14: LUV-Apo2L.0; ${ }^{213}$ 15: sTRAILtargeted stealth liposome; ${ }^{179}$ 16: TRAIL/Tf/Dox HSA-NPs; ${ }^{168}$ 17: immuno-LipoTRAIL; ${ }^{177}$ 18: Anti-CD3:TRAIL K12:TRAIL; ${ }^{196}$ 19: leukocytes coated with LUV-TRAIL-ES; ${ }^{178}$

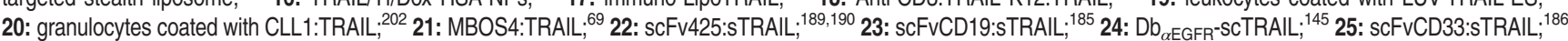
26: Anti-MCSP:TRAIL; ${ }^{188}$ 27: scFv-EHD2-scTRAIL; ${ }^{211}$ 28: scFvG28:TRAILmutRs; ${ }^{195}$ 29: scFvCD70:TRAILmutRs; ${ }^{70}$ 30: RGD-L-TRAIL; ${ }^{203}$ 31: CD40ed:TRAILed; ${ }^{214}$ 32: MSC. scFvCD20-sTRAIL; ${ }^{187}$ 33: ANG-CLP/PTX/pEGFP-hTRAIL; ${ }^{176}$ 34: sTRAIL-expressing E. coli DH5 $\alpha^{215}$

required further cross-linking by the FLAG-specific antibody M2. ${ }^{7}$ These constructs rendered promising results in vitro and also provided promising in vivo safety profiles in the different animal models, mainly rodents and nonhuman primates. ${ }^{8,31,133}$ However, both His-TRAIL and cross-linked FLAG-TRAIL were capable of killing freshly isolated primary human hepatocytes (PHH) in vitro. ${ }^{30,134,135}$ Most likely, the main reason for this hepatotoxicity was the formation of aberrant supramolecular aggregates owing to the interactions between the added tags. In particular, in the case of HisTRAIL, metal analysis showed an abnormally low molar ratio between zinc and the TRAIL trimer, implying that anomalous supramolecular structures may have formed. ${ }^{31}$ These findings suggested that TRAIL trimer stability may impact hepatotoxicity in vivo and turned the focus on potential liver toxicity of systemic TRAIL administration. 
The only recombinant form of TRAIL approved for use in clinical trials to date has been an untagged version of the molecule comprising residues 114-281 of TRAIL. This version, known as the aforementioned Apo2L.0 or AMG-951/ Dulanermin, appeared to be both active and safe as it worked well in several xenotransplant cancer models $8,84,128,133$ but did not kill freshly isolated $\mathrm{PHH}$ and was well tolerated by cynomolgus monkeys and chimpanzees. ${ }^{30,31,128,136}$ Consequently, Apo2L.0/Dulanermin was tested in the cancer patients where it indeed proved to be safe, though also disappointingly inactive..$^{25,26,137-141}$ Apo2L.0/Dulanermin is rather unstable, presenting low pharmacokinetic profiles, especially concerning its serum half-life with an extended distribution half-life $\left(t_{1 / 2} a\right)$ of only $3-5 \mathrm{~min}$ and an elimination half-life $\left(t_{1 / 2} \beta\right)$ of $20 \mathrm{~min}^{8,128}$ In addition, as previously mentioned, Apo2L.0/Dulanermin mainly induces activation of TRAIL-R1 and appears to be unable to potently activate TRAIL-R2. ${ }^{68,69}$

To address these issues, improved versions of TRAIL have been engineered to enhance its stability while retaining the proper trimer structure. The first approach that, interestingly, even predated the engineering of Apo2L.0/Dulanermin, was the inclusion of a specific trimerization domain, a modified leucine zipper motif (LZ-TRAIL) ${ }^{8}$ followed by the use of an isoleucine zipper (iz-TRAIL) ${ }^{30}$ at the $\mathrm{N}$ terminus of the extracellular domain. The addition of these trimerization motifs achieves robust stabilization of the TRAIL trimer by specific interactions between the modified leucine or isoleucine zipper domains that form stable triple helices. These first high-activity recombinant forms of TRAIL were significantly more active than Apo2L.0/Dulanermin, both in vitro and in vivo, and also exhibited better pharmacokinetic profiles in rodents with an extended distribution half-life $\left(t_{1 / 2} a\right)$ of $1.3 \mathrm{~h}$ and an elimination half-life $\left(t_{1 / 2} \beta\right)$ of $4.8 \mathrm{~h}$. Most importantly, however, these proteins showed neither specific toxicity on $\mathrm{PHH}$ ex vivo nor systemic toxicity in vivo in mice. 8,142

More recently, Berg et al. ${ }^{143}$ developed a new highly stable version of TRAIL by the incorporation of the tenascin-C (TNC) oligomerization domain (TNC-TRAIL), which stabilized the trimeric conformation in a similar fashion to LZ-TRAIL and izTRAIL. Besides, several groups recently developed novel versions of highly stable TRAIL trimers that build upon a single-chain TRAIL (scTRAIL) trimer. ${ }^{144,145}$ Contrarily to 'classic' approaches in which TRAIL is expressed from a monomer-encoding cDNA, scTRAIL is expressed as a single amino-acid sequence encoding a TRAIL trimer as three consecutive extracellular TRAIL domains that are fused in a head-to-tail configuration, inserting a short linker between each domain. Hence, once correctly folded, scTRAIL already forms an active TRAIL trimer, reducing the risk of unspecific aggregation of the monomers. The common feature of these constructs is their more stable trimerization, which enhances their pro-apoptotic potential so that they are even able to kill some of the cancer cell lines that are resistant to the lessactive Apo2L.0/Dulanermin. 8,30,142-145 In addition, these forms of recombinant TRAIL also exhibit increased in vivo half-lives, whereas the formation of higher-order, aberrant protein oligomers that can result in hepatotoxicity and systemic toxicity ${ }^{31}$ appears not to occur. $8,30,142,144,145$
Another strategy to improve the in vivo performance of TRAIL is based on covalently linking TRAIL to molecules known to have favorable pharmacokinetic properties such as human serum albumin (HSA) ${ }^{146}$ or polyethylene glycol (PEG). PEGylation is a process by which polymer chains of $P E G$ are added covalently to biomolecules such as peptides, proteins or antibodies. The resulting PEGylated biomolecules usually present improved pharmacokinetic properties and, consequently, enhanced therapeutic efficacy. ${ }^{147-149}$ Hence, PEGylated versions using site-specific N-terminal PEGylation of izTRAIL showed widely improved pharmacokinetic profiles in vivo and, furthermore, greatly augmented stability and solubility under physiological conditions. ${ }^{150-154}$ In addition, PEGylation improved TRAIL's efficacy at targeting cancer cells owing to the enhanced permeability and retention (EPR) effect, which will be discussed in more detail below.

\section{Targeting TRAIL to cancer cells}

An important obstacle when treating primary tumors effectively with TRAIL is that they are often intrinsically TRAIL-resistant, or acquire resistance when treated with TRAIL. Several studies have shown that co-administration of certain chemotherapeutic drugs can sensitize the cancer cells to TRAILinduced apoptosis. ${ }^{155-159}$ However, chemotherapeutics lack cancer cell selectivity and cause severe adverse effects by also targeting normal cells. Thus, this obstacle could be overcome by improving the specificity of TRAIL for cancer cells when used in combination with chemotherapeutics or other sensitizing compounds. Furthermore, targeted delivery of TRAIL specifically to the tumor would increase the local concentration and minimize dilution of the drug in circulation. Mainly two approaches of targeting methods have been pursued: (i) passive targeting based on the EPR effect and (ii) active targeting by using antibody fragments or peptides that target TRAIL to specific tumor-enriched antigens.

Passive targeting: combining TRAIL with nanoparticles. The nanoparticle (NP)-based systems have emerged as a promising means to improve drug delivery in vivo. ${ }^{160-162}$ Structurally, NPs have a diameter in the range of $50-150 \mathrm{~nm}$ and can be composed of a wide variety of compounds, including lipids and polymers. These compounds can be combined with different therapeutic molecules trapped inside the NPs and/or presented on the NP surface. Independent of the NP composition, they possess interesting and desirable general features such as improved pharmacokinetics, pharmacodynamics and in vivo stability of the therapeutic molecules encapsulated by them (Figure 2). Another important characteristic of NPs is the aforementioned EPR effect. Depending on the size and surface property of the NP in question, and given that blood and lymph vessel systems in tumors are thought to be leaky to macromolecules, NPs readily spill from capillaries and lymph vessels that vascularize tumor tissue. Consequently, the EPR effect allows the NPs to better target tumors than the therapeutic molecules alone. ${ }^{162-166}$ The optimal diameter of the NPs to take advantage of the EPR effect is in the range of $10-150 \mathrm{~nm}$. Regarding the EPR effect, many anticancer drug-containing nano-systems such as micelles, microspheres and liposomes 


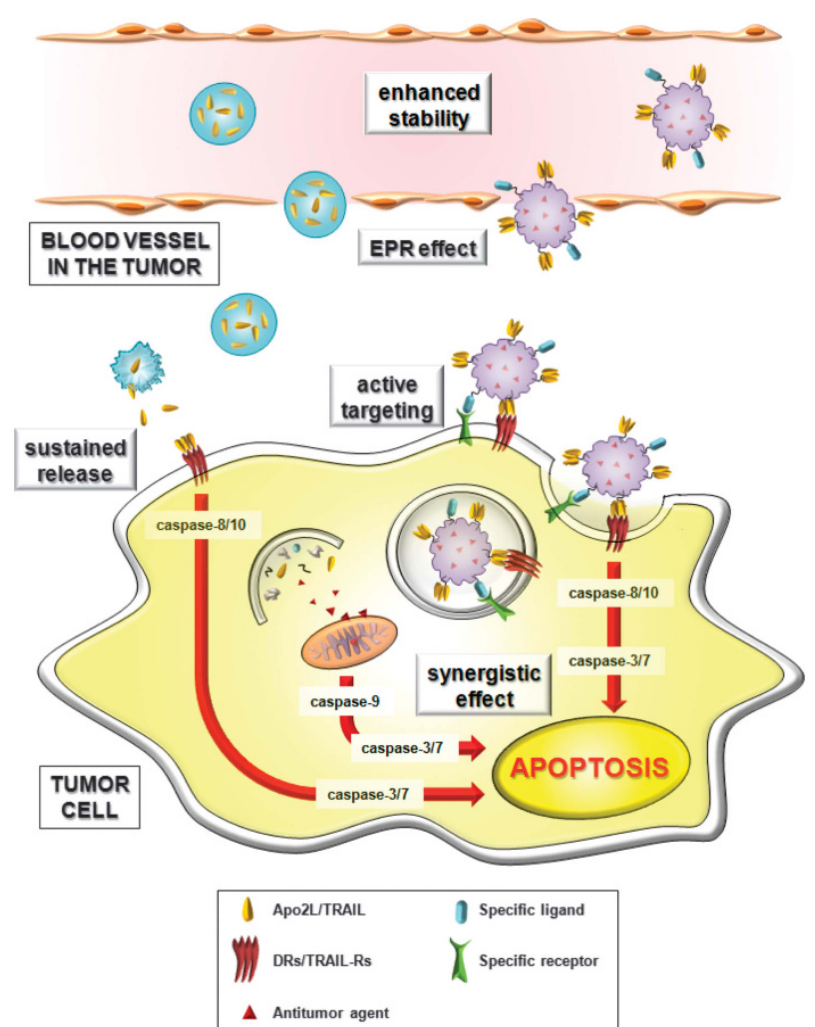

Figure 2 Main effects of nanoparticle-based formulations of TRAIL. Different formulations of TRAIL using nanoparticle-based methods have been recently developed, including liposomes. These experimental approaches show a variety of advantages that help to improve the therapeutic potential of TRAIL in cancer. Conjugation with nanoparticles increases the stability of TRAIL therefore increasing its half-life and allowing a sustained release in the tumor. The so-called enhanced permeability and retention (EPR) effect allows the nanoparticles to be more specific targeting tumors than the antitumor molecules alone. This passive targeting may be improved including different molecules in the nanoparticle composition that specifically target them to the tumor. Finally, nanoparticles loaded with other drugs than TRAIL, which specifically sensitize tumor cells to TRAIL and enhance its proapoptotic effect, may have a synergistic effect killing tumor cells

have been developed, and several NP products such as Doxil (Centocor Ortho Biotech Products, Horsham, PA, USA), DaunoXome (Diatos, Paris, France) and Genexol-PM (Samyang, Seoul, Korea) have already been approved for clinical use or are currently tested in clinical trials.

As summarized in Table 1, a number of TRAIL-containing NPs are currently being developed. To engineer the NP-core, different chemical compositions have been used such as human serum albumin, ${ }^{153,167,168}$ poly (lactic-co-glycolic) acid (PLGA) microspheres, ${ }^{151,152,169}$ a combination of PEGylated heparin and poly-L-lysine, ${ }^{154}$ magnetic ferric oxide ${ }^{170}$ or liposomes. ${ }^{67,171-179}$ Among them, thanks to their versatility, liposomes have emerged as the most versatile of these platforms. Moreover, liposomes can be easily modified sizeand composition-wise depending on the desired physicochemical properties. In addition, they represent a safe choice as liposomes have been widely studied and used in the clinic as drug carriers. ${ }^{180,181}$

Concerning the manner in which TRAIL is integrated with the NPs, there are two different strategies: (i) to encapsulate
TRAIL inside the particles so that they are released from the particle in a constant and stable manner; ${ }^{151-154,169,173-176}$ or (ii) to attach TRAIL to the surface of the nanoparticles so that TRAIL gets immobilized, resembling the physiological membrane-bound protein, increasing its bioactivity. ${ }^{168,170-172,177-179}$

An additional benefit of both strategies is the possibility to load NPs with additional drugs that could act in concert with TRAIL thereby enhancing its pro-apoptotic effect. In fact, the combination of TRAIL with doxorubicin ${ }^{151,168,173,174}$ or paclitaxel $^{76}$ in NPs has already been reported. In all the cases, the therapeutic effect was greatly enhanced by co-delivery of the chemotherapeutic agents with TRAIL, whereas no systemic toxicity was detected in vivo.

Besides the EPR effect, some authors have boosted the intrinsic tumor-targeting ability of NPs by functionalizing them with targeting molecules such as single-chain variable fragments (scFv), ${ }^{177}$ transferrin, allowing transferrin-mediated endocytosis of the NPs, ${ }^{168}$ or angiopep- $2,{ }^{176}$ a molecule that specifically targets the low-density lipoprotein receptor-related protein, which is highly expressed on the blood-brain barrier and glioma cells. ${ }^{182}$ Furthermore, angiopep-2 has recently not only been used for enhanced delivery across the blood-brain barrier, but also for targeting brain tumors by the so-called 'dual targeting effect'. 176

Active targeting: antigen-restricted activation of TRAIL receptors. An additional strategy to enhance TRAIL targeting is the use of domains or motifs that specifically target cancer cells or cells of the tumor stroma. Several groups have developed novel TRAIL constructs that have been fused to such domains. The resulting fusion proteins are intrinsically bivalent, maintaining the ability to engage TRAIL-DRs and simultaneously combining this with the specific targeting of an antigen expressed on the surface of particular tumor cells or cells in the tumor microenvironment.

Although antibodies would be an obvious choice to provide such targeting ability, whole immunoglobulins have a molecular weight of approximately $150 \mathrm{kDa}$, rendering them sterically less than ideal to be used as fusion domains. Single-chain variable-fragment (scFv) domains, by contrast, bear the advantage of maintaining antigen-specificity of full immunoglobulins, while presenting a much smaller size (around $25 \mathrm{kDa}$ ) allowing them to be readily fused recombinantly to other biotherapeutic such as TRAIL. ${ }^{183,184}$ Various such ScFv:TRAIL constructs have been developed (Table 2), targeting surface antigens known to be highly expressed by the cells of certain tumor types. These include FAP, ${ }^{69}$ CD19, ${ }^{185} \mathrm{CD}_{3},{ }^{186} \mathrm{CD} 20,{ }^{187} \mathrm{MCSP}$ (melanoma-associated chondroitin sulfate proteoglycan), ${ }^{188}$ ErbB2 (ref. 144) or epidermal growth factor receptor (EGFR). ${ }^{145,189-191} \mathrm{~A}$ variant of this experimental approach is the use of the Fn14:TRAIL fusion protein. ${ }^{192,193}$ In this case, the protein fused with TRAIL is not an ScFv, but a peptide corresponding to the extracellular domain of Fn14, the receptor for TWEAK/Apo3L (TNF-related weak inducer of apoptosis/Apo3L). TWEAK is a multifunctional cytokine involved in many cellular activities including proliferation, migration, differentiation, apoptosis, angiogenesis and inflammation, which is not only expressed by normal cells but also in tumor tissue (reviewed in ref. 194). An Fn14: 


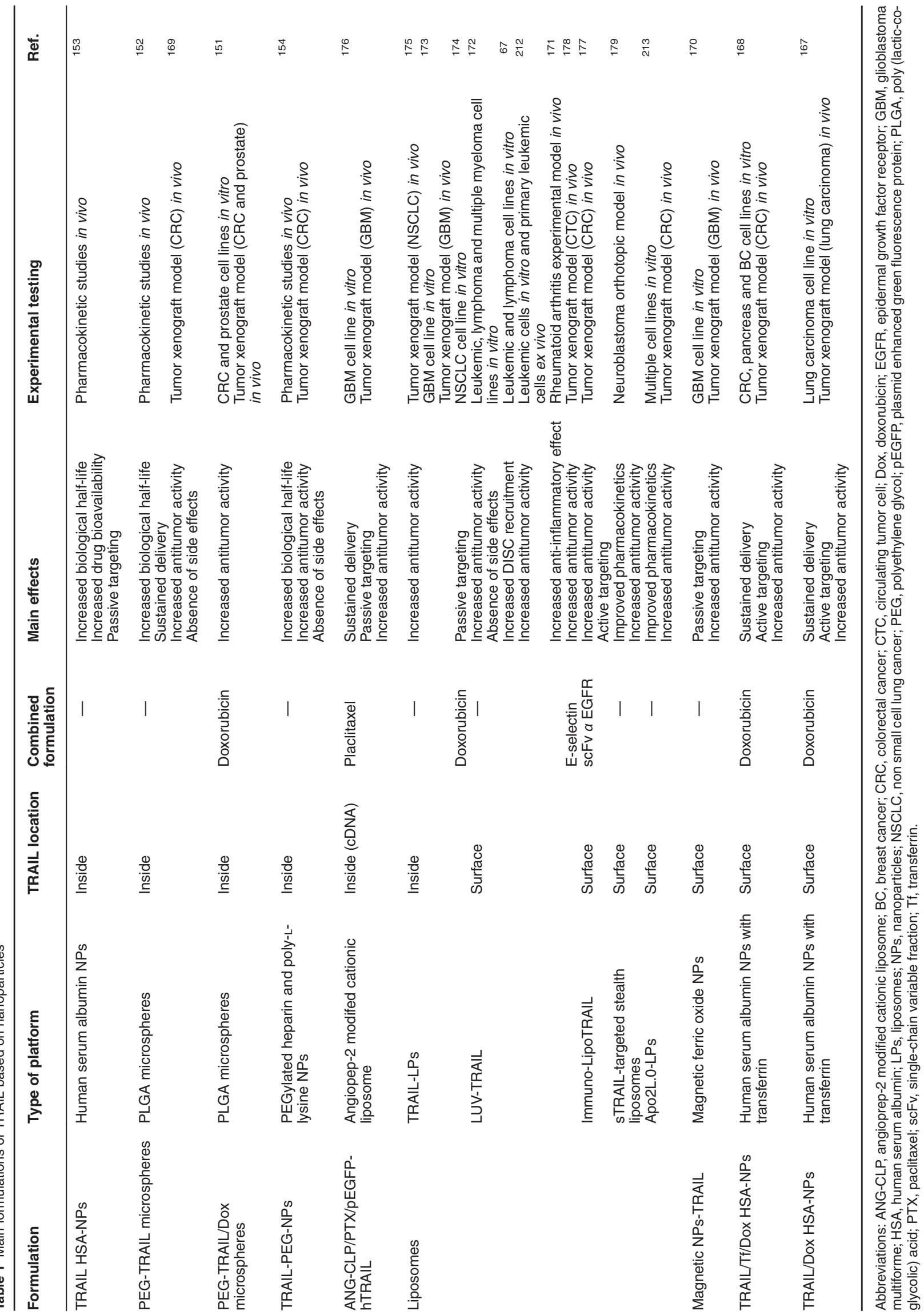


Table 2 Main formulations of TRAIL fusion proteins

\begin{tabular}{|c|c|c|c|c|}
\hline Fusion protein & Target & Main effects & Experimental testing & Ref. \\
\hline MBOS4:TRAIL & FAP & $\begin{array}{l}\text { Increased bioactivity } \\
\text { Active targeting }\end{array}$ & Fibrosarcoma cell lines in vitro & 69 \\
\hline CD40ed:TRAILed & CD40 & $\begin{array}{l}\text { Increased bioactivity } \\
\text { Active targeting }\end{array}$ & Fibrosarcoma cell lines in vitro & 214 \\
\hline \multirow[t]{2}{*}{ scFv425:sTRAIL } & \multirow[t]{2}{*}{ EGFR } & $\begin{array}{l}\text { Increased drug bioavailability } \\
\text { Active targeting } \\
\text { Absence of side effects }\end{array}$ & $\begin{array}{l}\text { Pharmacokinetic studies in vivo } \\
\text { Tumor xenograft model (RCC) in vivo }\end{array}$ & 189 \\
\hline & & Increased antitumor activity & Hematologic and solid tumor cell lines in vitro & 190 \\
\hline scFvCD19:sTRAIL & CD19 & $\begin{array}{l}\text { Active targeting } \\
\text { Absence of side effects } \\
\text { Increased antitumor activity }\end{array}$ & $\begin{array}{l}\text { Hematologic tumor cell lines and B-CLL primary cells in vitro } \\
\text { Tumor xenograft model (B-ALL) in vivo }\end{array}$ & 185 \\
\hline scFvCD33:sTRAIL & CD33 & $\begin{array}{l}\text { Active targeting } \\
\text { Increased antitumor activity }\end{array}$ & Hematologic tumor cell lines and AML primary cells in vitro & 186 \\
\hline Anti-MCSP:TRAIL & MCSP & $\begin{array}{l}\text { Active targeting } \\
\text { Absence of side effects } \\
\text { Increased antitumor activity }\end{array}$ & $\begin{array}{l}\text { Melanoma cell lines and normal primary cells in vitro } \\
\text { Tumor xenograft model (melanoma) in vivo }\end{array}$ & 188 \\
\hline $\mathrm{Db}_{\mathrm{aEGFR}}$-SCTRAIL & EGFR & $\begin{array}{l}\text { Active targeting } \\
\text { Absence of side effects } \\
\text { Increased antitumor activity }\end{array}$ & $\begin{array}{l}\mathrm{HCC} \text { and } \mathrm{CRC} \text { cell lines in vitro } \\
\text { Tumor xenograft model (CRC) in vivo }\end{array}$ & 145 \\
\hline $\begin{array}{l}\text { Anti-CD3:TRAIL } \\
\text { K12:TRAIL }\end{array}$ & $\begin{array}{l}\text { CD3 } \\
\text { CD7 }\end{array}$ & $\begin{array}{l}\text { Enhanced T-cell activity } \\
\text { Increased antitumor activity }\end{array}$ & $\begin{array}{l}\text { Hematologic, solid tumor cell lines and tumor primary cells } \\
\text { in vitro } \\
\text { Tumor xenograft model }(\mathrm{CRC}) \text { in vivo }\end{array}$ & 196 \\
\hline scFvCD70:TRAILmutRs & CD70 & $\begin{array}{l}\text { Increased bioactivity } \\
\text { Active targeting }\end{array}$ & Hematologic and solid tumor cell lines in vitro & 70 \\
\hline scFv:G28-TRAIL & CD40 & $\begin{array}{l}\text { Increased bioactivity } \\
\text { Active targeting } \\
\text { Induction of DC maturation }\end{array}$ & Fibrosarcoma cell lines in vitro & 195 \\
\hline MSC.scFvCD20-sTRAIL & CD20 & $\begin{array}{l}\text { Active targeting } \\
\text { Absence of side effects } \\
\text { Increased antitumor activity }\end{array}$ & $\begin{array}{l}\text { Hematologic tumor cell lines and normal primary cells in vitro } \\
\text { Tumor xenograft model (NHL) in vivo }\end{array}$ & 187 \\
\hline CLL1:TRAIL & CLL1 & $\begin{array}{l}\text { Enhanced T-cell activity } \\
\text { Increased antitumor activity } \\
\text { Absence of side effects }\end{array}$ & Hematologic and solid tumor cell lines in vitro & 202 \\
\hline RGD:TRAIL & Integrins & $\begin{array}{l}\text { Active targeting } \\
\text { Increased antitumor activity }\end{array}$ & $\begin{array}{l}\mathrm{BC} \text { and } \mathrm{CRC} \text { cell lines in vitro } \\
\text { Tumor xenograft model (NHL) in vivo }\end{array}$ & 203 \\
\hline scTRAIL: Fc (APG350) & - & Increased antitumor activity & $\begin{array}{l}\text { Several cell lines in vitro } \\
\text { Tumor xenograft model (CRC) in vivo }\end{array}$ & 209 \\
\hline scFv-EHD2-scTRAIL & - & $\begin{array}{l}\text { Increased antitumor activity } \\
\text { Active targeting }\end{array}$ & $\begin{array}{l}\text { Several cell lines in vitro } \\
\text { Tumor xenograft model (CRC) in vivo }\end{array}$ & 211 \\
\hline FN14:TRAIL & TWEAK & $\begin{array}{l}\text { Increased antitumor activity } \\
\text { Absence of side effects } \\
\text { Increased anti-inflammatory effect }\end{array}$ & $\begin{array}{l}\text { HCC cell lines in vitro } \\
\text { Tumor xenograft model (HCC) in vivo } \\
\text { Multiple sclerosis experimental model in vivo }\end{array}$ & 192 \\
\hline
\end{tabular}

Abbreviations: AML, acute myeloid leukemia; B-ALL, B-cell acute lymphoblastic leukemia; BC, breast cancer; B-CLL, B-cell chronic lymphocytic leukemia; CRC, colorectal carcinoma; DC, dendritic cell; EGFR, epidermal growth factor receptor; HCC, hepatocellular carcinoma; MCSP, melanoma-associated chondroitin sulfate proteoglycan; MSC, mesenchymal stem cells; NHL, non-Hodgkin's lymphoma; RCC, renal cell carcinoma; RGD, peptide with the sequence ACDCRGDCFC; scFv, single-chain variable region.

TRAIL fusion protein that showed increased bioactivity in an experimental model of multiple sclerosis ${ }^{193}$ also showed enhanced antitumor activity in vitro and in vivo against hepatocellular carcinoma. ${ }^{192}$ This activity relies on the ability of Fn14:TRAIL to interfere with TWEAK-Fn14 signaling in cancer cells and simultaneously trigger TRAIL-induced apoptosis. It is worth pointing out that some authors have constructed such fusion proteins using novel versions of TRAIL such as TNC-TRAIL and ScTRAIL to improve trimer stability. $^{70,144,145,195}$

An interesting additional variation to this approach, which has again been developed by several groups independently, is the targeting of TRAIL not to the surface of tumor cells but to that of immune cells via specific antigens expressed on their 
surface. In this regard, de Bruyn et al. ${ }^{196}$ use TRAIL fusion proteins with anti-CD3 or anti-CD7 scFv fragments. The aim is to improve the tumoricidal activity of $\mathrm{T}$ cells ex vivo by expanding their cytotoxic arsenal and to thereby potentially overcome the shortcomings of conventional adoptive T-cell therapies in achieving the desired therapeutic effect. ${ }^{197-201}$ With the intention to increase the tumoricidal capacity of another type of immune cells, a TRAIL fusion protein with CLL1 (C-type lectin-like molecule-1), has recently been developed. This fusion protein targets human granulocytes, attaching TRAIL to their surface. These granulocytes artificially armed with TRAIL not only increased TRAIL induced apoptosis but also potentiated antibody-mediated cytotoxicity of several therapeutic antibodies. ${ }^{202}$ In this line, El-Mesery et al. ${ }^{195}$ generated a CD40-directed scFv-TRAIL fusion protein using the above-mentioned TNC-TRAIL, which results in enhanced TRAIL-mediated apoptosis and robust induction of CD40-mediated maturation of dendritic cells that, in turn, could serve to potentiate immune response against tumors. Along similar lines, Trebing et al. ${ }^{70}$ developed scFv:lahCD70-TNCTRAIL, a fusion protein, which showed strongly enhanced apoptosis with CD70-restricted activity. In this case, the fusion protein would act via both, blocking the immunosuppressive activity of tumor cells expressing CD70 and stimulating their cell death. Another variation to this theme has been developed by Cao et al. ${ }^{203}$ who fused TRAIL to the peptide ACDCRGDCFC, which has high affinity for $a_{\mathrm{v}} \beta_{3}$ and $a_{\mathrm{v}} \beta_{5}$ integrins. Thereby, the authors aimed to target blood-forming capillaries within solid tumors as these highly express the $a_{\mathrm{v}} \beta_{3}$ integrin. ${ }^{204}$ Furthermore, $a_{\mathrm{v}} \beta_{3}$ and $a_{\mathrm{v}} \beta_{5}$ integrins are highly expressed on many tumor cells including on melanoma, ${ }^{205}$ colon, ${ }^{206}$ breast ${ }^{207}$ and ovarian ${ }^{208}$ cancer cells. The resulting construct showed specificity for the tumor neovasculature and enhanced apoptosis-inducing activity, both in vitro and in vivo. In general, all of the above-described constructs have demonstrated improved activity over non-fused versions of TRAIL or 'mock' versions that were unable to bind the respective specific surface antigens. Of note, some of these targeted constructs have been built using TRAIL constructs specific for TRAIL-R1 or TRAIL-R2, which allows for selective activation to maximize the efficiency of the apoptosis induction and minimize possible undesired activation of non-tumoral TRAIL-DRs. $^{70}$

In addition, there has been a recent wave of 'second generation' TRAIL-based constructs, centered on the concept of TRAIL trimer dimerization via domains that enable this in an appropriate spatial configuration. The first description of such a fusion protein $\left(\mathrm{Db}_{\mathrm{aEGFR}}\right.$-ScTRAIL, ${ }^{144}$ ) used a diabody as dimerization domain. In this case, the diabody had a dual role as it both stabilized the structure by acting as dimerization domain and provided targeting properties by recognizing EGFR, directing the molecule to EGFR-expressing cells. ${ }^{144}$ In a structurally similar manner, Gieffers et al. ${ }^{209}$ developed a dimer of TRAIL trimers by using the Fc-portion of human $\operatorname{IgG}_{1}$ as dimerization domain. In this case, the resulting recombinant protein lacks a specific targeting domain but, importantly, the authors showed that its apoptosis-inducing capacity, in contrast to that of TRAIL-DR-targeting antibodies, was indeed independent of Fcy receptor expression on proximal cells. ${ }^{210}$ Seifert et al., ${ }^{211}$ in turn, developed a new 'tetravalent'
TRAIL-based scFv-containing formulation that is composed of two TRAIL trimers and two ScFv regions fused together through the dimerization domain of IgE heavy chain domain 2 (EHD2). Physiologically, this domain acts by connecting the two heavy chains of an IgE molecule. The scFvs used in this construct recognize EGFR. Of note, all of these TRAIL-based constructs have been built as single-chain fusion proteins.

An additional effect of several of these constructs is that they bind to surface antigens through the $\mathrm{N}$-terminal part of the protein, while the C-terminal, pro-apoptotic domain of TRAIL, is exposed, thereby mimicking membrane-bound TRAIL. Thereby, these constructs also gain the ability to efficiently cross-link and activate TRAIL-DRs, consequently enhancing the pro-apoptotic effect. Cell surface antigen-bound TRAIL not only acts in an autocrine manner, by recognizing an antigen on a cancer cell and triggering TRAIL-induced apoptosis in that same cell, but can also act in a paracrine fashion: once the fusion protein is attached to a surface antigen on one cell, the TRAIL domain can induce apoptosis in neighboring cells, even though they may not express the surface antigen, minimizing the tumor's opportunities to evade treatment. However, whether this effect will always turn out to be beneficial, or may in certain cases specifically enhance unwanted effects beyond an acceptable level, remains to be determined.

Another characteristic of these constructs, thought to be advantageous in most cases, is the interaction with their specific cell surface receptors/targets which, depending on the construct in question, can lead to activation or inhibition of the signals normally transduced by these targets. Thus, depending on the type of cancer and regarding its phenotype, targeting of the cancer cell can be rationalized by choosing a specific antigen expressed by the tumor cells in question. This tumor antigen can be targeted, not only with directing purposes but also with the purpose of either activating or blocking it. Such an activity may synergize with the proapoptotic effect exerted by TRAIL-DR cross-linking via the TRAIL component of the recombinant protein in question.

\section{Conclusions and perspectives}

The ability of TRAIL to specifically kill tumor cells makes this cytokine a promising antitumor agent. In fact, numerous clinical trials using TRAIL-based therapies have been conducted. $^{32}$ However, the anticancer activities of the TRAIL-R agonists that have been tested in patients so far has been limited to disappointing. Moreover, recent research has demonstrated that TRAIL can induce, by far, more diverse effects than merely apoptosis, some of which being rather undesirable in the context of cancer therapy. Hence, it is of crucial importance to evaluate the different TRAIL-based therapies and how they differentially affect signaling very carefully before delivering them to patients. Moreover, the poor stability of untagged soluble TRAIL in vivo is not helpful with regard to its pharmacokinetic properties. These problems are currently being addressed by the development of a plethora of new formulations and ways of administration of novel recombinant forms of TRAIL and other TRAIL-R agonists as explained in this review. Yet, the promising results that have been obtained in vivo with some of these new formulations of TRAIL must be further endorsed over the next years in a wider 
range of cancer types, and in more complex models, such as genetically engineered mouse models as well as in tumor models representing the heterogeneity of human cancers and, ultimately, in the cancer clinic.

\section{Conflict of Interest}

AA and LM-L have filed a patent application (W02011020933) for the use of liposome-bound Apo2L/TRAIL. HW is a co-founder and shareholder of Apogenix $\mathrm{GmbH}$, Heidelberg, Germany, and a named inventor on the patent that underlies the development of the TRAIL-R2-specific antibody Conatumumab. The remaining authors declare no conflict of interest.

Acknowledgements. This work was supported by Grants PI13/00416 (LM-L) from the Instituto de Salud Carlos III, SAF2013-48626-C2-1-R from the Ministerio de Ciencia e Innovación (Spain) and the European Social Fund. DdM was supported by a pre-doctoral fellowship from Gobierno de Aragón and HW was supported by a program grant from Cancer Research UK.

1. Melero I, Berman DM, Aznar MA, Korman AJ, Gracia JLP, Haanen J. Evolving synergistic combinations of targeted immunotherapies to combat cancer. Nat Rev Cancer 2015; 15 : 457-472.

2. Bracci L, Schiavoni G, Sistigu A, Belardelli F. Immune-based mechanisms of cytotoxic chemotherapy: implications for the design of novel and rationale-based combined treatments against cancer. Cell Death Differ 2014; 21: 15-25.

3. Kaufmann T, Simon HU. Targeting disease by immunomodulation. Cell Death Differ 2015; 22: $185-186$.

4. Bremer $\mathrm{E}$, de Bruyn $\mathrm{M}$, Wajant $\mathrm{H}$, Helfrich W. Targeted cancer immunotherapy using ligands of the tumor necrosis factor super-family. Curr Drug Targets 2009; 10: 94-103.

5. Gasparini C, Vecchi Brumatti L, Monasta L, Zauli G. TRAlL-based therapeutic approaches for the treatment of pediatric malignancies. Curr Med Chem 2013; 20: 2254-2271.

6. Pitti RM, Marsters SA, Ruppert S, Donahue CJ, Moore A, Ashkenazi A. Induction of apoptosis by Apo-2 ligand, a new member of the tumor necrosis factor cytokine family. J Biol Chem 1996; 271: 12687-12690.

7. Wiley SR, Schooley K, Smolak PJ, Din WS, Huang C-P, Nicholl JK et al. Identification and characterization of a new member of the TNF family that induces apoptosis. Immunity 1995; 3: 673-682.

8. Walczak H, Miller RE, Ariail K, Gliniak B, Griffith TS, Kubin M et al. Tumoricidal activity of tumor necrosis factor-related apoptosis-inducing ligand in vivo. Nat Med 1999; 5: 157-163.

9. Pan G, O'Rourke K, Chinnaiyan AM, Gentz R, Ebner R, Ni J et al. The receptor for the cytotoxic ligand TRAIL. Science 1997; 276: 111-113.

10. Schneider P, Bodmer JL, Thome M, Hofmann K, Holler N, Tschopp J. Characterization of two receptors for TRAIL. FEBS Lett 1997; 416: 329-334.

11. MacFarlane M, Ahmad M, Srinivasula SM, Fernandes-Alnemri T, Cohen GM, Alnemri ES. Identification and molecular cloning of two novel receptors for the cytotoxic ligand TRAIL. J Biol Chem 1997; 272: 25417-25420.

12. Screaton GR, Mongkolsapaya J, Xu XN, Cowper AE, McMichael AJ, Bell JI. TRICK2, a new alternatively spliced receptor that transduces the cytotoxic signal from TRAIL. Curr Biol 1997; 7: 693-696.

13. Chaudhary PM, Eby M, Jasmin A, Bookwalter A, Murray J, Hood L. Death receptor 5, a new member of the TNFR family, and DR4 induce FADD-dependent apoptosis and activate the NF-kappaB pathway. Immunity 1997; 7: 821-830.

14. Walczak H, Degli-Esposti MA, Johnson RS, Smolak PJ, Waugh JY, Boiani N et al. TRAILR2: a novel apoptosis-mediating receptor for TRAIL. EMBO J 1997; 16: 5386-5397.

15. Kayagaki N, Yamaguchi N, Nakayama M, Takeda K, Akiba H, Tsutsui $\mathrm{H}$ et al. Expression and function of TNF-related apoptosis-inducing ligand on murine activated NK cells. J Immunol 1999; 163: 1906-1913.

16. Kayagaki N, Yamaguchi N, Nakayama M, Kawasaki A, Akiba $\mathrm{H}$, Okumura $\mathrm{K}$ et al. Involvement of TNF-related apoptosis-inducing ligand in human CD4+ T cell-mediated cytotoxicity. J Immunol 1999; 162: 2639-2647.

17. Martínez-Lorenzo MJ, Alava MA, Gamen S, Kim KJ, Chuntharapai A, Piñeiro A et al. Involvement of APO2 ligand/TRAIL in activation-induced death of Jurkat and human peripheral blood T cells. Eur J Immunol 1998; 28: 2714-2725.

18. Sträter J, Walczak H, Pukrop T, Von Müller L, Hasel C, Kornmann M et al. TRAIL and its receptors in the colonic epithelium: a putative role in the defense of viral infections. Gastroenterology 2002; 122: 659-666.

19. Sträter J, Hinz U, Walczak H, Mechtersheimer G, Koretz K, Herfarth $\mathrm{C}$ et al. Expression of TRAIL and TRAIL receptors in colon carcinoma: TRAIL-R1 is an independent prognostic parameter. Clin Cancer Res 2002; 8: 3734-3740.

20. Spierings DC, de Vries EG, Timens W, Groen HJ, Boezen HM, de Jong S. Expression of TRAIL and TRAIL death receptors in stage III non-small cell lung cancer tumors. Clin Cancer Res 2003; 9: 3397-3405.
21. Kurbanov BM, Geilen CC, Fecker LF, Orfanos CE, Eberle J. Efficient TRAIL-R1/DR4mediated apoptosis in melanoma cells by tumor necrosis factor-related apoptosis-inducing ligand (TRAIL). J Invest Dermatol 2005; 125: 1010-1019.

22. Voortman J, Resende TP, Abou El Hassan MA, Giaccone G, Kruyt FA. TRAIL therapy in non-small cell lung cancer cells: sensitization to death receptor-mediated apoptosis by proteasome inhibitor bortezomib. Mol Cancer Ther 2007; 6: 2103-2112.

23. Morizot A, Merino D, Lalaoui N, Jacquemin G, Granci V, lessi E et al. Chemotherapy overcomes TRAIL-R4-mediated TRAIL resistance at the DISC level. Cell Death Differ 2011; 18: $700-711$.

24. Micheau O, Shirley S, Dufour F. Death receptors as targets in cancer. Br J Pharmacol 2013; 169: 1723-1744.

25. Herbst RS, Eckhardt SG, Kurzrock R, Ebbinghaus S, O'Dwyer PJ, Gordon MS et al. Phase I dose-escalation study of recombinant human Apo2L/TRAIL, a dual proapoptotic receptor agonist, in patients with advanced cancer. J Clin Oncol 2010; 28: 2839-2846.

26. Soria JC, Smit E, Khayat D, Besse B, Yang X, Hsu CP et al. Phase $1 \mathrm{~b}$ study of dulanermin (recombinant human Apo2L/TRAIL) in combination with paclitaxel, carboplatin, and bevacizumab in patients with advanced non-squamous non-small-cell lung cancer. J Clin Oncol 2010; 28: 1527-1533.

27. Tuthill MH, Montinaro A, Zinngrebe J, Prieske K, Draber P, Prieske S et al. TRAIL-R2specific antibodies and recombinant TRAIL can synergise to kill cancer cells. Oncogene 2014; 9: 156.

28. Koschny R, Holland H, Sykora J, Haas TL, Sprick MR, Ganten TM et al. Bortezomib sensitizes primary human astrocytoma cells of WHO grades I to IV for tumor necrosis factor-related apoptosis-inducing ligand-induced apoptosis. Clin Cancer Res 2007; 13: 3403-3412.

29. Koschny R, Ganten TM, Sykora J, Haas TL, Sprick MR, Kolb A et al. TRAIL/bortezomib cotreatment is potentially hepatotoxic but induces cancer-specific apoptosis within a therapeutic window. Hepatology 2007; 45: 649-658.

30. Ganten TM, Koschny R, Sykora J, Schulze-Bergkamen H, Buchler P, Haas TL et al. Preclinical differentiation between apparently safe and potentially hepatotoxic applications of TRAIL either alone or in combination with chemotherapeutic drugs. Clin Cancer Res 2006; 12: 2640-2646.

31. Lawrence D, Shahrokh Z, Marsters S, Achilles K, Shih D, Mounho B et al. Differential hepatocyte toxicity of recombinant Apo2L/TRAIL versions. Nat Med 2001; 7: 383-385.

32. Lemke J, von Karstedt S, Zinngrebe J, Walczak H. Getting TRAlL back on track for cancer therapy. Cell Death Differ 2014; 21: 1350-1364.

33. Hymowitz SG, Christinger HW, Fuh G, Ultsch M, O'Connell M, Kelley RF et al. Triggering cell death: the crystal structure of Apo2L/TRAIL in a complex with death receptor 5. Mol Cell 1999; 4: 563-571.

34. Hymowitz SG, O'Connell MP, Ultsch MH, Hurst A, Totpal K, Ashkenazi A et al. A unique zinc-binding site revealed by a high-resolution X-ray structure of homotrimeric Apo2L TRAIL. Biochemistry 2000; 39: 633-640.

35. Cha SS, Kim MS, Choi YH, Sung BJ, Shin NK, Shin HC et al. 2.8 A resolution crystal structure of human TRAIL, a cytokine with selective antitumor activity. Immunity 1999; 11: 253-261.

36. Emery JG, McDonnell P, Burke MB, Deen KC, Lyn S, Silverman C et al. Osteoprotegerin is a receptor for the cytotoxic ligand TRAIL. J Biol Chem 1998; 273: 14363-14367.

37. Pan G, O'Rourke K, Chinnaiyan AM, Gentz R, Ebner R, Ni J et al. The receptor for the cytotoxic ligand TRAIL. Science 1997; 276: 111-113.

38. Marsters SA, Sheridan JP, Pitti RM, Huang A, Skubatch M, Baldwin D et al. A novel receptor for Apo2L/TRAIL contains a truncated death domain. Curr Biol 1997; 7: 1003-1006.

39. Wallach D, Boldin M, Varfolomeev E, Beyaert R, Vandenabeele P, Fiers W. Cell death induction by receptors of the TNF family: towards a molecular understanding. FEBS Letters 1997; 410: 96-106.

40. Degli-Esposti MA, Dougall WC, Smolak PJ, Waugh JY, Smith CA, Goodwin RG. The novel receptor TRAIL-R4 induces NF-kappaB and protects against TRAlL-mediated apoptosis, yet retains an incomplete death domain. Immunity 1997; 7: 813-820.

41. Degli-Esposti MA, Smolak PJ, Walczak H, Waugh J, Huang CP, DuBose RF et al. Cloning and characterization of TRAIL-R3, a novel member of the emerging TRAIL receptor family. J Exp Med 1997; 186: 1165-1170.

42. Merino D, Lalaoui N, Morizot A, Schneider P, Solary E, Micheau O. Differential inhibition of TRAIL-mediated DR5-DISC formation by decoy receptors 1 and 2. Mol Cell Biol 2006; 26: 7046-7055.

43. Clancy L, Mruk K, Archer K, Woelfel M, Mongkolsapaya J, Screaton G et al. Preligand assembly domain-mediated ligand-independent association between TRAIL receptor 4 (TR4) and TR2 regulates TRAlL-induced apoptosis. Proc Natl Acad Sci USA 2005; 102: 18099-18104.

44. Gomez-Benito M, Martinez-Lorenzo MJ, Anel A, Marzo I, Naval J. Membrane expression of DR4, DR5 and caspase-8 levels, but not Mcl-1, determine sensitivity of human myeloma cells to Apo2L/TRAIL. Exp Cell Res 2007; 313: 2378-2388.

45. Kelley RF, Totpal K, Lindstrom SH, Mathieu M, Billeci K, Deforge L et al. Receptor-selective mutants of apoptosis-inducing ligand 2/tumor necrosis factor-related apoptosis-inducing ligand reveal a greater contribution of death receptor (DR) 5 than DR4 to apoptosis signaling. J Biol Chem 2005; 280: 2205-2212.

46. Ganten TM, Haas TL, Sykora J, Stahl H, Sprick MR, Fas SC et al. Enhanced caspase-8 recruitment to and activation at the DISC is critical for sensitisation of human hepatocellular 
carcinoma cells to TRAIL-induced apoptosis by chemotherapeutic drugs. Cell Death Differ 2004; 11 Suppl 1: S86-S96.

47. Bodmer JL, Holler N, Reynard S, Vinciguerra P, Schneider P, Juo P et al. TRAIL receptor-2 signals apoptosis through FADD and caspase-8. Nat Cell Biol 2000; 2: 241-243.

48. Dickens LS, Boyd RS, Jukes-Jones R, Hughes MA, Robinson GL, Fairall L et al. A death effector domain chain DISC model reveals a crucial role for caspase-8 chain assembly in mediating apoptotic cell death. Mol Cell 2012; 47: 291-305.

49. Kuang AA, Diehl GE, Zhang J, Winoto A. FADD is required for DR4- and DR5-mediated apoptosis: lack of trail-induced apoptosis in FADD-deficient mouse embryonic fibroblasts. J Biol Chem 2000; 275: 25065-25068.

50. Peter ME. The TRAIL DISCussion: it is FADD and caspase-8! Cell Death Differ 2000; 7: 759-760.

51. Kischkel FC, Lawrence DA, Chuntharapai A, Schow P, Kim KJ, Ashkenazi A. Apo2L/ TRAIL-dependent recruitment of endogenous FADD and caspase-8 to death receptors 4 and 5. Immunity 2000; 12: 611-620.

52. Chen M, Wang J. Initiator caspases in apoptosis signaling pathways. Apoptosis 2002; 7: 313-319.

53. Riedl SJ, Shi Y. Molecular mechanisms of caspase regulation during apoptosis. Nat Rev Mol Cell Biol 2004; 5: 897-907.

54. Salvesen GS, Dixit VM. Caspase activation: the induced-proximity model. Proc Natl Acad Sci USA 1999; 96: 10964-10967.

55. Muhlethaler-Mottet A, Flahaut M, Bourloud KB, Nardou K, Coulon A, Liberman J et al. Individual caspase-10 isoforms play distinct and opposing roles in the initiation of death receptor-mediated tumour cell apoptosis. Cell Death Dis 2011; 2: e125.

56. Ozoren N, El-Deiry WS. Defining characteristics of Types I and II apoptotic cells in response to TRAIL. Neoplasia 2002; 4: 551-557.

57. Rudner J, Jendrossek V, Lauber K, Daniel PT, Wesselborg S, Belka C. Type I and type II reactions in TRAIL-induced apoptosis - results from dose-response studies. Oncogene 2005; 24: 130-140.

58. Grinberg M, Sarig R, Zaltsman Y, Frumkin D, Grammatikakis N, Reuveny E et al. tBID Homooligomerizes in the mitochondrial membrane to induce apoptosis. J Biol Chem 2002; 277: 12237-12245.

59. Li H, Zhu H, Xu C-j, Yuan J. Cleavage of BID by caspase 8 mediates the mitochondrial damage in the Fas pathway of apoptosis. Cell 1998; 94: 491-501.

60. Luo X, Budihardjo I, Zou H, Slaughter C, Wang X. Bid, a Bcl2 interacting protein, mediates cytochrome $c$ release from mitochondria in response to activation of cell surface death receptors. Cell 1998; 94: 481-490.

61. Wei MC, Lindsten T, Mootha VK, Weiler S, Gross A, Ashiya M et al. tBID, a membranetargeted death ligand, oligomerizes BAK to release cytochrome c. Genes Dev 2000; 14: 2060-2071.

62. Holcik M, Korneluk RG. XIAP, the guardian angel. Nat Rev Mol Cell Biol 2001; 2: 550-556.

63. Jost PJ, Grabow S, Gray D, McKenzie MD, Nachbur U, Huang DC et al. XIAP discriminates between type I and type II FAS-induced apoptosis. Nature 2009; 460: 1035-1039.

64. Modjtahedi N, Giordanetto F, Madeo F, Kroemer G. Apoptosis-inducing factor: vital and lethal. Trends Cell Biol 2006; 16: 264-272.

65. Pardo J, Perez-Galan P, Gamen S, Marzo I, Monleon I, Kaspar AA et al. A role of the mitochondrial apoptosis-inducing factor in granulysin-induced apoptosis. J Immunol 2001; 167: 1222-1229.

66. Truneh A, Sharma S, Silverman C, Khandekar S, Reddy MP, Deen KC et al. Temperaturesensitive differential affinity of TRAIL for its receptors. DR5 is the highest affinity receptor. $J$ Biol Chem 2000; 275: 23319-23325.

67. De Miguel D, Gallego-Lleyda A, Anel A, Martinez-Lostao L. Liposome-bound TRAIL induces superior DR5 clustering and enhanced DISC recruitment in histiocytic lymphoma U937 cells. Leuk Res 2015; 39: 657-666.

68. Muhlenbeck F, Schneider P, Bodmer JL, Schwenzer R, Hauser A, Schubert G et al. The tumor necrosis factor-related apoptosis-inducing ligand receptors TRAIL-R1 and TRAIL-R2 have distinct cross-linking requirements for initiation of apoptosis and are non-redundant in JNK activation. J Biol Chem 2000; 275: 32208-32213.

69. Wajant H, Moosmayer D, Wuest T, Bartke T, Gerlach E, Schonherr U et al. Differential activation of TRAIL-R1 and -2 by soluble and membrane TRAIL allows selective surface antigen-directed activation of TRAIL-R2 by a soluble TRAIL derivative. Oncogene 2001; 20: 4101-4106.

70. Trebing J, El-Mesery M, Schafer V, Weisenberger D, Siegmund D, Silence K et al. CD70restricted specific activation of TRAILR1 or TRAILR2 using ScFv-targeted TRAIL mutants. Cell Death Dis 2014; 5: e1035.

71. Holler N, Tardivel A, Kovacsovics-Bankowski M, Hertig S, Gaide O, Martinon F et al. Two adjacent trimeric Fas ligands are required for Fas signaling and formation of a deathinducing signaling complex. Mol Cell Biol 2003; 23: 1428-1440.

72. Wyzgol A, Muller N, Fick A, Munkel S, Grigoleit GU, Pfizenmaier K et al. Trimer stabilization, oligomerization, and antibody-mediated cell surface immobilization improve the activity of soluble trimers of CD27L, CD40L, 41BBL, and glucocorticoid-induced TNF receptor ligand. J Immunol 2009; 183: 1851-1861.

73. Schneider P, Holler N, Bodmer JL, Hahne M, Frei K, Fontana A et al. Conversion of membrane-bound Fas(CD95) ligand to its soluble form is associated with downregulation of its proapoptotic activity and loss of liver toxicity. $J$ Exp Med 1998; 187: 1205-1213.
74. O' Reilly LA, Tai L, Lee L, Kruse EA, Grabow S, Fairlie WD et al. Membrane-bound Fas ligand only is essential for Fas-induced apoptosis. Nature 2009; 461: 659-663.

75. Carrington PE, Sandu C, Wei Y, Hill JM, Morisawa G, Huang T et al. The structure of FADD and its mode of interaction with procaspase-8. Mol Cell 2006; 22: 599-610.

76. Scott FL, Stec B, Pop C, Dobaczewska MK, Lee JJ, Monosov E et al. The Fas-FADD death domain complex structure unravels signalling by receptor clustering. Nature 2009; 457: 1019-1022.

77. Dickens LS, Powley IR, Hughes MA, MacFarlane M. The 'complexities' of life and death: death receptor signalling platforms. Exp Cell Res 2012; 318: 1269-1277.

78. Graves JD, Kordich JJ, Huang TH, Piasecki J, Bush TL, Sullivan T et al. Apo2L/TRAIL and the death receptor 5 agonist antibody AMG 655 cooperate to promote receptor clustering and antitumor activity. Cancer Cell 2014; 26: 177-189.

79. MacFarlane M, Inoue S, Kohlhaas SL, Majid A, Harper N, Kennedy DBJ et al. Chronic lymphocytic leukemic cells exhibit apoptotic signaling via TRAIL-R1. Cell Death Differ 2005; 12: 773-782.

80. MacFarlane M, Kohlhaas SL, Sutcliffe MJ, Dyer MJ, Cohen GM. TRAIL receptor-selective mutants signal to apoptosis via TRAIL-R1 in primary lymphoid malignancies. Cancer Res 2005; 65: 11265-11270.

81. Szegezdi E, Reis CR, van der Sloot AM, Natoni A, O'Reilly A, Reeve J et al. Targeting AML through DR4 with a novel variant of rhTRAIL. J Cell Mol Med 2011; 15: 2216-2231.

82. Lemke J, Noack A, Adam D, Tchikov V, Bertsch U, Röder C et al. TRAlL signaling is mediated by DR4 in pancreatic tumor cells despite the expression of functional DR5. J Mol Med 2010; 88: 729-740.

83. van der Sloot AM, Tur V, Szegezdi E, Mullally MM, Cool RH, Samali A et al. Designed tumor necrosis factor-related apoptosis-inducing ligand variants initiating apoptosis exclusively via the DR5 receptor. Proc Natl Acad Sci USA 2006; 103: 8634-8639.

84. Kelley SK, Ashkenazi A. Targeting death receptors in cancer with Apo2L/TRAIL. Curr Opin Pharmacol 2004; 4: 333-339.

85. Tur V, van der Sloot AM, Reis CR, Szegezdi E, Cool RH, Samali A et al. DR4-selective tumor necrosis factor-related apoptosis-inducing ligand (TRAIL) variants obtained by structure-based design. J Biol Chem 2008; 283: 20560-20568.

86. Gasparian ME, Chernyak BV, Dolgikh DA, Yagolovich AV, Popova EN, Sycheva AM et al. Generation of new TRAIL mutants DR5-A and DR5-B with improved selectivity to death receptor 5. Apoptosis 2009; 14: 778-787.

87. Reis CR, van der Sloot AM, Natoni A, Szegezdi E, Setroikromo R, Meijer M et al. Rapid and efficient cancer cell killing mediated by high-affinity death receptor homotrimerizing TRAIL variants. Cell Death Dis 2010; 1: e83.

88. Irmler M, Thome M, Hahne M, Schneider P, Hofmann K, Steiner V et al. Inhibition of death receptor signals by cellular FLIP. Nature 1997; 388: 190-195.

89. Tschopp J, Irmler M, Thome M. Inhibition of fas death signals by FLIPs. Curr Opin Immunol 1998; 10: 552-558

90. Krueger A, Schmitz I, Baumann S, Krammer PH, Kirchhoff S. Cellular FLICE-inhibitory protein splice variants inhibit different steps of caspase-8 activation at the CD95 deathinducing signaling complex. J Biol Chem 2001; 276: 20633-20640.

91. Weinlich R, Oberst A, Dillon CP, Janke LJ, Milasta S, Lukens JR et al. Protective roles for caspase-8 and cFLIP in adult homeostasis. Cell Rep 2013; 5: 340-348.

92. Pop C, Oberst A, Drag M, Van Raam BJ, Riedl SJ, Green DR et al. FLIP(L) induces caspase 8 activity in the absence of interdomain caspase 8 cleavage and alters substrate specificity. Biochem J 2011; 433: 447-457.

93. Feoktistova M, Geserick P, Kellert B, Dimitrova DP, Langlais C, Hupe M et al. clAPs block Ripoptosome formation, a RIP1/caspase-8 containing intracellular cell death complex differentially regulated by cFLIP isoforms. Mol Cell 2011; 43: 449-463.

94. Micheau O, Thome M, Schneider P, Holler N, Tschopp J, Nicholson DW et al. The long form of FLIP is an activator of caspase-8 at the Fas death-inducing signaling complex. J Biol Chem 2002; 277: 45162-45171.

95. Chang DW, Xing Z, Pan Y, Algeciras-Schimnich A, Barnhart BC, Yaish-Ohad S et al. c-FLIP $(L)$ is a dual function regulator for caspase-8 activation and CD95-mediated apoptosis. EMBO J 2002; 21: 3704-3714.

96. Boatright KM, Deis C, Denault JB, Sutherlin DP, Salvesen GS. Activation of caspases-8 and -10 by FLIP(L). Biochem J 2004; 382(Pt 2): 651-657.

97. Oberst A, Dillon CP, Weinlich R, McCormick LL, Fitzgerald P, Pop C et al. Catalytic activity of the caspase-8-FLIP(L) complex inhibits RIPK3-dependent necrosis. Nature 2011; 471: 363-367.

98. van Raam BJ, Salvesen GS. Proliferative versus apoptotic functions of caspase-8 Hetero or homo: the caspase-8 dimer controls cell fate. Biochim Biophys Acta 2012; 1824: 113-122.

99. Burns TF, El-Deiry WS. Identification of inhibitors of TRAIL-induced death (ITIDs) in the TRAIL-sensitive colon carcinoma cell line SW480 using a genetic approach. J Biol Chem 2001; 276: 37879-37886.

100. Riley JS, Hutchinson R, McArt DG, Crawford N, Holohan C, Paul I et al. Prognostic and therapeutic relevance of FLIP and procaspase-8 overexpression in non-small cell lung cancer. Cell Death Dis 2013; 5: 481.

101. Guseva NV, Rokhlin OW, Taghiyev AF, Cohen MB. Unique resistance of breast carcinoma cell line T47D to TRAIL but not anti-Fas is linked to p43cFLIP(L). Breast Cancer Res Treat 2008; 107: 349-357.

102. Geserick P, Drewniok C, Hupe M, Haas TL, Diessenbacher P, Sprick MR et al. Suppression of CFLIP is sufficient to sensitize human melanoma cells to TRAIL- and CD95L-mediated apoptosis. Oncogene 2008; 27: 3211-3220. 
103. Balsas P, López-Royuela N, Galán-Malo P, Anel A, Marzo I, Naval J. Cooperation between Apo2L/TRAlL and bortezomib in multiple myeloma apoptosis. Biochem Pharmacol 2009; 77: 804-812

104. Palacios C, Yerbes R, Lopez-Rivas A. Flavopiridol induces cellular FLICE-inhibitory protein degradation by the proteasome and promotes TRAIL-induced early signaling and apoptosis in breast tumor cells. Cancer Res 2006; 66: 8858-8869.

105. Lemke J, von Karstedt S, Abd El Hay M, Conti A, Arce F, Montinaro A et al. Selective CDK9 inhibition overcomes TRAIL resistance by concomitant suppression of cFlip and Mcl-1. Cell Death Differ 2014; 21: 491-502.

106. Bratton S, Lewis J, Butterworth M, Duckett C, Cohen G. XIAP inhibition of caspase-3 preserves its association with the Apaf-1 apoptosome and prevents CD95-and Bax-induced apoptosis. Cell Death Differ 2002; 9: 881-892.

107. Wagner KW, Punnoose EA, Januario T, Lawrence DA, Pitti RM, Lancaster $K$ et al. Deathreceptor O-glycosylation controls tumor-cell sensitivity to the proapoptotic ligand Apo2L/ TRAIL. Nat Med 2007; 13: 1070-1077.

108. Jin Z, Li Y, Pitti R, Lawrence D, Pham VC, Lill JR et al. Cullin3-based polyubiquitination and p62-dependent aggregation of caspase-8 mediate extrinsic apoptosis signaling. Cell 2009; 137: $721-735$

109. Austin CD, Lawrence DA, Peden AA, Varfolomeev EE, Totpal K, De Maziere AM et al. Death-receptor activation halts clathrin-dependent endocytosis. Proc Natl Acad Sci USA 2006; 103: 10283-10288.

110. Lin Y, Devin A, Cook A, Keane MM, Kelliher M, Lipkowitz S et al. The death domain kinase RIP is essential for TRAIL (Apo2L)-induced activation of IkappaB kinase and c-Jun N-terminal kinase. Mol Cell Biol 2000; 20: 6638-6645.

111. Morel J, Audo R, Hahne M, Combe B. Tumor necrosis factor-related apoptosis-inducing ligand (TRAIL) induces rheumatoid arthritis synovial fibroblast proliferation through mitogen-activated protein kinases and phosphatidylinositol 3-kinase/Akt. J Biol Chem 2005; 280: $15709-15718$

112. Tran SE, Holmstrom TH, Ahonen M, Kahari VM, Eriksson JE. MAPK/ERK overrides the apoptotic signaling from Fas, TNF, and TRAIL receptors. J Biol Chem 2001; 276: 16484-16490

113. Grunert M, Gottschalk K, Kapahnke J, Gundisch S, Kieser A, Jeremias I. The adaptor protein FADD and the initiator caspase-8 mediate activation of NF-kappaB by TRAIL. Cell Death Dis 2012; 3: e414.

114. Varfolomeev E, Maecker H, Sharp D, Lawrence D, Renz M, Vucic D et al. Molecular determinants of kinase pathway activation by Apo2 ligand/tumor necrosis factor-related apoptosis-inducing ligand. J Biol Chem 2005; 280: 40599-40608.

115. Azijli K, Yuvaraj S, van Roosmalen I, Flach K, Giovannetti E, Peters GJ et al. MAPK p38 and JNK have opposing activities on TRAIL-induced apoptosis activation in NSCLC H460 cells that involves RIP1 and caspase-8 and is mediated by Mcl-1. Apoptosis 2013; 18: 851-860.

116. Trauzold A, Siegmund D, Schniewind B, Sipos B, Egberts J, Zorenkov D et al. TRAIL promotes metastasis of human pancreatic ductal adenocarcinoma. Oncogene 2006; 25 : 7434-7439.

117. Falschlehner $\mathrm{C}$, Emmerich $\mathrm{CH}$, Gerlach B, Walczak H. TRAIL signalling: decisions between life and death. Int J Biochem Cell Biol 2007; 39: 1462-1475.

118. Hoogwater FJ, Nijkamp MW, Smakman N, Steller EJ, Emmink BL, Westendorp BF et al. Oncogenic K-Ras turns death receptors into metastasis-promoting receptors in human and mouse colorectal cancer cells. Gastroenterology 2010; 138: 2357-2367.

119. von Karstedt S, Conti A, Nobis M, Montinaro A, Hartwig T, Lemke J et al. Cancer cellautonomous TRAIL-R signaling promotes KRAS-driven cancer progression, invasion, and metastasis. Cancer Cell 2015; 27: 561-573.

120. Holland PM. Death receptor agonist therapies for cancer, which is the right TRAIL? Cytokine Growth Factor Rev 2014; 25: 185-193.

121. Dimberg LY, Anderson CK, Camidge R, Behbakht K, Thorburn A, Ford HL. On the TRAIL to successful cancer therapy? Predicting and counteracting resistance against TRAIL-based therapeutics. Oncogene 2013; 32: 1341-1350.

122. Thorburn A, Behbakht $\mathrm{K}$, Ford $\mathrm{H}$. TRAlL receptor-targeted therapeutics: resistance mechanisms and strategies to avoid them. Drug Resist Updat 2008; 11: 17-24.

123. Zhang L, Fang B. Mechanisms of resistance to TRAIL-induced apoptosis in cancer. Cancer Gene Ther 2005; 12: 228-237.

124. Lovric MM, Hawkins CJ. TRAIL treatment provokes mutations in surviving cells. Oncogene 2010; 29: 5048-5060

125. Joy AM, Beaudry CE, Tran NL, Ponce FA, Holz DR, Demuth T et al. Migrating glioma cells activate the PI3-K pathway and display decreased susceptibility to apoptosis. J Cell Sci 2003; 116(Pt 21): 4409-4417.

126. Sanlioglu AD, Dirice E, Aydin C, Erin N, Koksoy S, Sanlioglu S. Surface TRAIL decoy receptor-4 expression is correlated with TRAIL resistance in MCF7 breast cancer cells. BMC Cancer 2005; 5 : 54.

127. Sanlioglu AD, Korcum AF, Pestereli E, Erdogan G, Karaveli S, Savas B et al. TRAIL death receptor-4 expression positively correlates with the tumor grade in breast cancer patients with invasive ductal carcinoma. Int J Radiat Oncol Biol Phys 2007; 69: 716-723.

128. Kelley SK, Harris LA, Xie D, Deforge L, Totpal K, Bussiere J et al. Preclinical studies to predict the disposition of Apo2L/tumor necrosis factor-related apoptosis-inducing ligand in humans: characterization of in vivo efficacy, pharmacokinetics, and safety. J Pharmacol Exp Ther 2001; 299: 31-38.

129. Xiang H, Nguyen CB, Kelley SK, Dybdal N, Escandon E. Tissue distribution, stability, and pharmacokinetics of Apo2 ligand/tumor necrosis factor-related apoptosis-inducing ligand in human colon carcinoma COLO205 tumor-bearing nude mice. Drug Metab Dispos 2004; 32 : 1230-1238.

130. Adams C, Totpal K, Lawrence D, Marsters S, Pitti R, Yee S et al. Structural and functional analysis of the interaction between the agonistic monoclonal antibody Apomab and the proapoptotic receptor DR5. Cell Death Differ 2008; 15: 751-761.

131. Dhein J, Daniel PT, Trauth BC, Oehm A, Moller P, Krammer PH. Induction of apoptosis by monoclonal antibody anti-APO-1 class switch variants is dependent on cross-linking of APO-1 cell surface antigens. J Immunol 1992; 149: 3166-3173.

132. Youn YS, Shin MJ, Chae SY, Jin CH, Kim TH, Lee KC. Biological and physicochemical evaluation of the conformational stability of tumor necrosis factor-related apoptosis-inducing ligand (TRAIL). Biotechnol Lett 2007; 29: 713-721.

133. Ashkenazi A, Pai RC, Fong S, Leung S, Lawrence DA, Marsters SA et al. Safety and antitumor activity of recombinant soluble Apo2 ligand. J Clin Invest 1999; 104: 155-162.

134. Ichikawa K, Liu W, Zhao L, Wang Z, Liu D, Ohtsuka T et al. Tumoricidal activity of a novel anti-human DR5 monoclonal antibody without hepatocyte cytotoxicity. Nat Med 2001; 7: 954-960.

135. Jo M, Kim TH, Seol DW, Esplen JE, Dorko K, Billiar TR et al. Apoptosis induced in normal human hepatocytes by tumor necrosis factor-related apoptosis-inducing ligand. Nat $\mathrm{Med}$ 2000; 6: 564-567.

136. Hao C, Song JH, Hsi B, Lewis J, Song DK, Petruk KC et al. TRAIL inhibits tumor growth but is nontoxic to human hepatocytes in chimeric mice. Cancer Res 2004; 64: 8502-8506.

137. Kasubhai SM, Bendell JC, Kozloff M, Kapp AV, Ashkenazi A, Royer-Joo S et al. Phase lb study of dulanermin combined with FOLFIRI (with or without bevacizumab [BV]) in previously treated patients (Pts) with metastatic colorectal cancer (mCRC). J Clin Oncol 2012; 30 (suppl; abstr 3543).

138. Soria JC, Mark Z, Zatloukal P, Szima B, Albert I, Juhasz E et al. Randomized phase II study of dulanermin in combination with paclitaxel, carboplatin, and bevacizumab in advanced non-small-cell lung cancer. J Clin Oncol 2011; 29: 4442-4451.

139. Wainberg ZA, Messersmith WA, Peddi PF, Kapp AV, Ashkenazi A, Royer-Joo S et al. A phase 1B study of dulanermin in combination with modified FOLFOX6 plus bevacizumab in patients with metastatic colorectal cancer. Clin Colorectal Cancer 2013; 12: 248-254.

140. Yee L, Burris HA, Kozloff M, Wainberg Z, Pao M, Skettino S et al. Phase Ib study of recombinant human Apo2L/TRAIL plus irinotecan and cetuximab or FOLFIRI in metastatic colorectal cancer (mCRC) patients (pts): preliminary results. J Clin Oncol 2009; 27: 15s (suppl; abstr 4129).

141. Yee L, Fanale M, Dimick K, Calvert S, Robins C, Ing J et al. A phase IB safety and pharmacokinetic (PK) study of recombinant human Apo2L/TRAIL in combination with rituximab in patients with low-grade non-Hodgkin lymphoma. 2007 ASCO Annual Meeting Proceedings (Post-Meeting Edition). J Clin Oncol 2007; 25(June 20 Supplement): 8078.

142. Rozanov DV, Savinov AY, Golubkov VS, Rozanova OL, Postnova TI, Sergienko EA et al. Engineering a leucine zipper-TRAIL homotrimer with improved cytotoxicity in tumor cells. Mol Cancer Ther 2009; 8: 1515-1525.

143. Berg D, Lehne M, Muller N, Siegmund D, Munkel S, Sebald W et al. Enforced covalent trimerization increases the activity of the TNF ligand family members TRAIL and CD95L. Cell Death Differ 2007; 14: 2021-2034.

144. Schneider B, Munkel S, Krippner-Heidenreich A, Grunwald I, Wels WS, Wajant H et al. Potent antitumoral activity of TRAIL through generation of tumor-targeted single-chain fusion proteins. Cell Death Dis 2010; 1: e68.

145. Siegemund M, Pollak N, Seifert O, Wahl K, Hanak K, Vogel A et al. Superior antitumoral activity of dimerized targeted single-chain TRAIL fusion proteins under retention of tumor selectivity. Cell Death Dis 2012; 3: e295.

146. Muller N, Schneider B, Pfizenmaier K, Wajant H. Superior serum half life of albumin tagged TNF ligands. Biochem Biophys Res Commun 2010; 396: 793-799.

147. Crawford J. Clinical benefits of pegylated proteins in oncology. Cancer Treat Rev 2002; 28: 1-2.

148. Crawford J. Clinical uses of pegylated pharmaceuticals in oncology. Cancer Treat Rev 2002; 28: 7-11

149. Harris JM, Chess RB. Effect of pegylation on pharmaceuticals. Nat Rev Drug Discov 2003 2: 214-221.

150. Chae SY, Kim TH, Park K, Jin CH, Son S, Lee S et al. Improved antitumor activity and tumor targeting of $\mathrm{NH}(2)$-terminal-specific PEGylated tumor necrosis factor-related apoptosisinducing ligand. Mol Cancer Ther 2010; 9: 1719-1729.

151. Jiang HH, Kim TH, Lee S, Chen X, Youn YS, Lee KC. PEGylated TNF-related apoptosisinducing ligand (TRAIL) for effective tumor combination therapy. Biomaterials 2011; 32 . 8529-8537.

152. Kim TH, Jiang HH, Park CW, Youn YS, Lee S, Chen X et al. PEGylated TNF-related apoptosis-inducing ligand (TRAIL)-loaded sustained release PLGA microspheres for enhanced stability and antitumor activity. J Control Release 2011; 150: 63-69.

153. Kim TH, Jiang HH, Youn YS, Park CW, Lim SM, Jin CH et al. Preparation and characterization of Apo2L/TNF-related apoptosis-inducing ligand-loaded human serum albumin nanoparticles with improved stability and tumor distribution. J Pharm Sci 2011; 100: 482-491.

154. Lim SM, Kim TH, Jiang HH, Park CW, Lee S, Chen X et al. Improved biological half-life and anti-tumor activity of TNF-related apoptosis-inducing ligand (TRAIL) using PEG-exposed nanoparticles. Biomaterials 2011; 32: 3538-3546.

155. Koschny R, Walczak H, Ganten T. The promise of TRAIL_-potential and risks of a novel anticancer therapy. J Mol Med 2007; 85: 923-935. 
156. Kruyt FA. TRAIL and cancer therapy. Cancer Lett 2008; 263: 14-25.

157. Mahalingam D, Szegezdi E, Keane M, de Jong S, Samali A. TRAIL receptor signalling and modulation: are we on the right TRAIL? Cancer Treat Rev 2009; 35: 280-288.

158. Mellier G, Huang S, Shenoy K, Pervaiz S. TRAlLing death in cancer. Mol Aspects Med 2010; 31: 93-112.

159. Newsom-Davis T, Prieske S, Walczak H. Is TRAIL the holy grail of cancer therapy? Apoptosis 2009; 14: 607-623.

160. Davis ME, Chen ZG, Shin DM. Nanoparticle therapeutics: an emerging treatment modality for cancer. Nat Rev Drug Discov 2008; 7: 771-782.

161. Maeda H, Bharate GY, Daruwalla J. Polymeric drugs for efficient tumor-targeted drug delivery based on EPR-effect. Eur J Pharm Biopharm 2009; 71: 409-419.

162. Stylianopoulos T. EPR-effect: utilizing size-dependent nanoparticle delivery to solid tumors. Ther Deliv 2013; 4: 421-423.

163. Fang J, Nakamura $\mathrm{H}$, Maeda $\mathrm{H}$. The EPR effect: unique features of tumor blood vessels for drug delivery, factors involved, and limitations and augmentation of the effect. Adv Drug Deliv Rev 2011; 63: 136-151.

164. Maeda H. Tumor-selective delivery of macromolecular drugs via the EPR effect: background and future prospects. Bioconjug Chem 2010; 21: 797-802.

165. Matsumura $Y$, Maeda $H$. A new concept for macromolecular therapeutics in cance chemotherapy: mechanism of tumoritropic accumulation of proteins and the antitumor agent smancs. Cancer Res 1986; 46(12 Pt 1): 6387-6392.

166. Torchilin V. Tumor delivery of macromolecular drugs based on the EPR effect. Adv Drug Deliv Rev 2011; 63: 131-135.

167. Choi SH, Byeon HJ, Choi JS, Thao L, Kim I, Lee ES et al. Inhalable self-assembled albumin nanoparticles for treating drug-resistant lung cancer. J Control Release 2015; 197 199-207.

168. Bae S, Ma K, Kim TH, Lee ES, Oh KT, Park ES et al. Doxorubicin-loaded human serum albumin nanoparticles surface-modified with TNF-related apoptosis-inducing ligand and transferrin for targeting multiple tumor types. Biomaterials 2012; 33 1536-1546.

169. Kim H, Jeong D, Kang HE, Lee KC, Na K. A sulfate polysaccharide/TNF-related apoptosisinducing ligand (TRAIL) complex for the long-term delivery of TRAIL in poly(lactic-coglycolic acid) (PLGA) microspheres. J Pharm Pharmacol 2013; 65: 11-21.

170. Perlstein B, Finniss SA, Miller C, Okhrimenko H, Kazimirsky G, Cazacu S et al. TRAIL conjugated to nanoparticles exhibits increased anti-tumor activities in glioma cells and glioma stem cells in vitro and in vivo. Neuro Oncol 2013; 15: 29-40.

171. Martinez-Lostao L, Garcia-Alvarez F, Basanez G, Alegre-Aguaron E, Desportes P, Larrad $\mathrm{L}$ et al. Liposome-bound APO2L/TRAIL is an effective treatment in a rabbit model of rheumatoid arthritis. Arthritis Rheum 2010; 62: 2272-2282.

172. De Miguel D, Basanez G, Sanchez D, Malo PG, Marzo I, Larrad L et al. Liposomes decorated with Apo2L/TRAIL overcome chemoresistance of human hematologic tumor cells. Mol Pharm 2013; 10: 893-904.

173. Guo L, Fan L, Pang Z, Ren J, Ren Y, Li J et al. TRAIL and doxorubicin combination enhances anti-glioblastoma effect based on passive tumor targeting of liposomes. J Control Release 2011; 154: 93-102.

174. Guo L, Fan L, Ren J, Pang Z, Ren Y, Li $\mathrm{J}$ et al. A novel combination of TRAlL and doxorubicin enhances antitumor effect based on passive tumor-targeting of liposomes. Nanotechnology 2011; 22: 265105 .

175. Guo L, Fan L, Ren J, Pang Z, Ren Y, Li J et al. Combination of TRAIL and actinomycin D liposomes enhances antitumor effect in non-small cell lung cancer. Int $J$ Nanomedicine 2012; 7: 1449-1460.

176. Sun X, Pang Z, Ye H, Qiu B, Guo L, Li J et al. Co-delivery of pEGFP-hTRAIL and paclitaxe to brain glioma mediated by an angiopep-conjugated liposome. Biomaterials 2012; 33: 916-924.

177. Seifert O, Pollak N, Nusser A, Steiniger F, Ruger R, Pfizenmaier $\mathrm{K}$ et al. ImmunoLipoTRAIL: targeted delivery of TRAIL-functionalized liposomal nanoparticles. Bioconjug Chem 2014; 25: 879-887.

178. Mitchell MJ, Wayne E, Rana K, Schaffer CB, King MR. TRAlL-coated leukocytes that kill cancer cells in the circulation. Proc Natl Acad Sci USA 2014; 111: 930-935.

179. Loi M, Becherini P, Emionite L, Giacomini A, Cossu I, Destefanis E et al. sTRAIL coupled to liposomes improves its pharmacokinetic profile and overcomes neuroblastoma tumour resistance in combination with Bortezomib. J Control Release 2014; 192: 157-166.

180. Fan $Y$, Zhang $Q$. Development of liposomal formulations: from concept to clinical investigations. Asian J Pharm Sci 2013; 8: 81-87.

181. Arajo Lopes SCd, Santos Giuberti Cd, Ribeiro TG, Santos Ferreira Dd, Amaral Leite E, Cristina M. Liposomes as carriers of anticancer drugs. In: Rangel L (ed). Cancer Treatment - Conventional and Innovative Approaches. InTech.: Viena, Austria, 2013.

182. Ke W, Shao K, Huang R, Han L, Liu Y, Li J et al. Gene delivery targeted to the brain using an Angiopep-conjugated polyethyleneglycol-modified polyamidoamine dendrimer. Biomaterials 2009; 30: 6976-6985

183. de Bruyn M, Bremer E, Helfrich W. Antibody-based fusion proteins to target death receptors in cancer. Cancer Lett 2013; 332: 175-183.

184. Kortt AA, Dolezal O, Power BE, Hudson PJ. Dimeric and trimeric antibodies: high avidity scFvs for cancer targeting. Biomol Eng 2001; 18: 95-108.

185. Stieglmaier J, Bremer E, Kellner C, Liebig TM, ten Cate B, Peipp M et al. Selective induction of apoptosis in leukemic B-lymphoid cells by a CD19-specific TRAIL fusion protein. Cancer Immunol Immunother 2008; 57: 233-246.
186. ten Cate B, Bremer E, de Bruyn M, Bijma T, Samplonius D, Schwemmlein M et al. A novel AML-selective TRAIL fusion protein that is superior to Gemtuzumab Ozogamicin in terms of in vitro selectivity, activity and stability. Leukemia 2009; 23: 1389-1397.

187. Yan C, Li S, Li Z, Peng H, Yuan X, Jiang L et al. Human umbilical cord mesenchymal stem cells as vehicles of CD20-specific TRAIL fusion protein delivery: a double-target therapy against non-Hodgkin's lymphoma. Mol Pharm 2013; 10: 142-151.

188. de Bruyn M, Rybczynska AA, Wei Y, Schwenkert M, Fey GH, Dierckx RA et al. Melanomaassociated Chondroitin Sulfate Proteoglycan (MCSP)-targeted delivery of soluble TRAIL potently inhibits melanoma outgrowth in vitro and in vivo. Mol Cancer 2010; 9: 301.

189. Bremer E, de Bruyn M, Samplonius DF, Bijma T, ten Cate B, de Leij LF et al. Targeted delivery of a designed STRAIL mutant results in superior apoptotic activity towards EGFRpositive tumor cells. J Mol Med (Berl) 2008; 86: 909-924.

190. Bremer E, van Dam GM, de Bruyn M, van Riezen M, Dijkstra M, Kamps G et al. Potent systemic anticancer activity of adenovirally expressed EGFR-selective TRAIL fusion protein. Mol Ther 2008; 16: 1919-1926.

191. Wahl K, Siegemund M, Lehner F, Vondran F, Nussler A, Langer F et al. Increased apoptosis induction in hepatocellular carcinoma by a novel tumor-targeted TRAIL fusion protein combined with bortezomib. Hepatology 2013; 57: 625-636.

192. Aronin A, Amsili S, Prigozhina TB, Tzdaka K, Rachmilewitz J, Shani N et al. Fn14*TRAIL effectively inhibits hepatocellular carcinoma growth. PLoS One 2013; 8: e77050.

193. Razmara M, Hilliard B, Ziarani AK, Murali R, Yellayi S, Ghazanfar M et al. Fn14-TRAIL, a chimeric intercellular signal exchanger, attenuates experimental autoimmune encephalomyelitis. Am J Pathol 2009; 174: 460-474.

194. Winkles JA. The TWEAK-Fn14 cytokine-receptor axis: discovery, biology and therapeutic targeting. Nat Rev Drug Discov 2008; 7: 411-425.

195. El-Mesery M, Trebing J, Schafer V, Weisenberger D, Siegmund D, Wajant H. CD40directed SCFv-TRAIL fusion proteins induce CD40-restricted tumor cell death and activate dendritic cells. Cell Death Dis 2013; 4: e916.

196. de Bruyn M, Wei Y, Wiersma VR, Samplonius DF, Klip HG, van der Zee AG et al. Cell surface delivery of TRAIL strongly augments the tumoricidal activity of T cells. Clin Cancer Res 2011; 17: 5626-5637.

197. Abouzahr-Rifai S, Hasmim M, Boukerche H, Hamelin J, Janji B, Jalil A et al. Resistance of tumor cells to cytolytic T lymphocytes involves Rho-GTPases and focal adhesion kinase activation. J Biol Chem 2008; 283: 31665-31672.

198. Chouaib S, Meslin F, Thiery J, Mami-Chouaib F. Tumor resistance to specific lysis: a major hurdle for successful immunotherapy of cancer. Clin Immunol 2009; 130: 34-40.

199. Hallermalm K, De Geer A, Kiessling R, Levitsky V, Levitskaya J. Autocrine secretion of Fas ligand shields tumor cells from Fas-mediated killing by cytotoxic lymphocytes. Cancer Res 2004; 64: 6775-6782.

200. Lee HM, Timme TL, Thompson TC. Resistance to lysis by cytotoxic T cells: a dominant effect in metastatic mouse prostate cancer cells. Cancer Res 2000; 60: 1927-1933.

201. Otten HG, van Ginkel WG, Hagenbeek A, Petersen EJ. Prevalence and clinical significance of resistance to perforin- and FAS-mediated cell death in leukemia. Leukemia 2004; 18: $1401-1405$

202. Wiersma VR, de Bruyn M, Shi C, Gooden MJ, Wouters MC, Samplonius DF et al. C-type lectin-like molecule-1 (CLL1)-targeted TRAIL augments the tumoricidal activity of granulocytes and potentiates therapeutic antibody-dependent cell-mediated cytotoxicity. MAbs 2015; 7: 321-330.

203. Cao L, Du P, Jiang SH, Jin GH, Huang QL, Hua ZC. Enhancement of antitumor properties of TRAIL by targeted delivery to the tumor neovasculature. Mol Cancer Ther 2008; 7 : $851-861$.

204. Max R, Gerritsen RR, Nooijen PT, Goodman SL, Sutter A, Keilholz U et al. Immunohistochemical analysis of integrin alpha vbeta3 expression on tumor-associated vessels of human carcinomas. Int J Cancer 1997; 71: 320-324.

205. Natali PG, Hamby CV, Felding-Habermann B, Liang B, Nicotra MR, Di Filippo F et al. Clinical significance of alpha(v)beta3 integrin and intercellular adhesion molecule-1 expression in cutaneous malignant melanoma lesions. Cancer Res 1997; 57: 1554-1560.

206. Kemperman H, Wijnands YM, Roos E. alphaV Integrins on HT-29 colon carcinoma cells: adhesion to fibronectin is mediated solely by small amounts of alphaVbeta6, and alphaVbeta5 is codistributed with actin fibers. Exp Cell Res 1997; 234: 156-164.

207. Arap W, Pasqualini R, Ruoslahti E. Cancer treatment by targeted drug delivery to tumor vasculature in a mouse model. Science 1998; 279: 377-380.

208. Carreiras F, Denoux Y, Staedel C, Lehmann M, Sichel F, Gauduchon P. Expression and localization of alpha $v$ integrins and their ligand vitronectin in normal ovarian epithelium and in ovarian carcinoma. Gynecol Oncol 1996; 62: 260-267.

209. Gieffers C, Kluge M, Merz C, Sykora J, Thiemann M, Schaal R et al. APG350 induces superior clustering of TRAIL receptors and shows therapeutic antitumor efficacy independent of cross-linking via Fcgamma receptors. Mol Cancer Ther 2013; 12: 2735-2747.

210. Wilson NS, Yang B, Yang A, Loeser S, Marsters S, Lawrence D et al. An Fcgamma receptor-dependent mechanism drives antibody-mediated target-receptor signaling in cancer cells. Cancer Cell 2011; 19: 101-113.

211. Seifert O, Plappert A, Fellermeier S, Siegemund M, Pfizenmaier K, Kontermann RE. Tetravalent antibody-scTRAIL fusion proteins with improved properties. Mol Cancer Ther 2014; 13: 101-111.

212. De Miguel D, Gallego-Lleyda A, Galan-Malo P, Rodriguez-Vigil C, Marzo I, Anel A et al. Immunotherapy with liposome-bound TRAIL overcomes partial protection to soluble 
TRAIL-induced apoptosis offered by down-regulation of Bim in leukemic cells. Clin Transl Oncol 2015; 17: 657-667.

213. Nair PM, Flores H, Gogineni A, Marsters S, Lawrence DA, Kelley RF et al. Enhancing the antitumor efficacy of a cell-surface death ligand by covalent membrane display. Proc Natl Acad Sci USA 2015; 112: 5679-5684.

214. Assohou-Luty C, Gerspach J, Siegmund D, Muller N, Huard B, Tiegs G et al. A CD40 CD95L fusion protein interferes with CD40L-induced prosurvival signaling and allows membrane CD40L-restricted activation of CD95. J Mol Med (Berl) 2006; 84: 785-797.

215. Zhang HY, Man JH, Liang B, Zhou T, Wang CH, Li T et al. Tumor-targeted delivery of biologically active TRAIL protein. Cancer Gene Ther 2010; 17: 334-343. (c) (1) (\$) $\odot$ This work is licensed under a Creative Commons Attribution-NonCommercial-NoDerivs 4.0 International License. The images or other third party material in this article are included in the article's Creative Commons license, unless indicated otherwise in the credit line; if the material is not included under the Creative Commons license, users will need to obtain permission from the license holder to reproduce the material. To view a copy of this license, visit http://creativecommons.org/licenses/by-nc-nd/4.0/ 